\title{
Deciphering temperature, pressure and oxygen-activity conditions of chlorite formation
}

\author{
OLIVIER VIDAL ${ }^{1, *}{ }^{*}{ }^{\dagger}$, PIERRE LANARI ${ }^{2}$, MANUEL MUNOZ ${ }^{1}$, \\ FRANCK BOURDELLE ${ }^{3}$ AND VINCENT DE ANDRADE 4 \\ ${ }^{1}$ Isterre, CNRS, Université Grenoble Alpes, 1381 Rue de la Piscine, BP 53, Grenoble Cedex 09 38041, France \\ ${ }^{2}$ Department of Geological Sciences, University of Bern Baltzerstrasse 1+3, Bern CH3012, Switzerland \\ ${ }^{3}$ LGCgE, Université Lille, Bât. SN5, Villeneuve d'Ascq 59655, France \\ ${ }^{4}$ Argonne National Laboratory, 9700 South Cass Ave, Bldg 438-B007, Lemont, IL 60439, USA
}

(Received 1 November 2015; revised 1 May 2016; Guest editor: Jeff Walker)

\begin{abstract}
The advantages and limits of empirical, semi-empirical and thermodynamic methods devoted to the estimation of chlorite-formation temperature are discussed briefly. The results of semiempirical and thermodynamic approaches with different assumptions regarding the redox state of iron in chlorite are compared for a large set of natural data covering a range of pressure conditions from a few hundred bars to $18 \mathrm{kbar}$ and temperature from 100 to $500^{\circ} \mathrm{C}$. The $\mathrm{T}-X \mathrm{Fe}^{3+}$ evolution estimated using the thermodynamic approach of Vidal et al. (2005) shows a systematic increase in $X \mathrm{Fe}^{3+}$ with decreasing temperature, which is compatible with the decrease in $a \mathrm{O}_{2}$ buffered by magnetite- or hematite-chlorite equilibrium. This trend as well as the observed increase in vacancies in chlorite with decreasing temperature is interpreted as the incorporation of $\mathrm{Fe}^{3+}$-sudoite. The standard-state properties of this endmember have been derived to reproduce the observed $T-a \mathrm{O}_{2}-X \mathrm{Fe}^{3+}$ evolutions. It can be used to estimate $T-a \mathrm{O}_{2}-X \mathrm{Fe}^{3}$ values with a Chl-Qtz- $\mathrm{H}_{2} \mathrm{O}$ multi-equilibrium approach. When combining our results with those of other studies published recently, it appears that thermodynamic approaches and mapping techniques developed for metamorphic rocks can be used to discuss the conditions of formation of very low-grade rocks where kinetics is much more sluggish than in metamorphic rocks. This requires use of appropriate analytical tools and techniques with a spatial resolution of a few hundred nanometres.
\end{abstract}

KEYwords: chlorite, oxidation state, thermodynamics.

In the 1980 s and 1990 s, several empirical calibrations were proposed to link the tetrahedral $\mathrm{Al}$ or vacancy content of chlorite with temperature (Cathelineau \& Nieva, 1985; Kranidiotis \& MacLean, 1987; Cathelineau, 1988; Hillier \& Velde, 1991; Jowett, 1991; Zang \& Fyfe, 1995). Although these approaches are still used widely

\footnotetext{
*E-mail: olivier.vidal@ujf-grenoble.fr

${ }^{\dagger}$ This work was originally presented during the session 'The many faces of chlorite', part of the Euroclay 2015 conference held in July 2015 in Edinburgh, UK.
}

DOI: $10.1180 /$ claymin.2016.051.4.06 for low-grade rocks, the lack of theoretical backgrounds and the reliability of the temperatures estimated have been criticized (e.g. de Caritat et al., 1993; Essene \& Peacor, 1995; Essene, 2009; Bourdelle et al., 2013a), and their application to metamorphic rocks remains questionable (Vidal et al., 2006). The thermodynamic models of chlorite proposed by several authors (e.g. Vidal et al., 2001, 2005, 2006; Walshe, 1986; Lanari et al., 2014) offer an alternative to empirical approaches. Vidal et al. (2006) and Lanari et al. (2014) proposed thermodynamic models constrained from high-temperature experiments and natural data from low- to medium-grade metamorphic rocks. They showed that these models could be used to constrain the temperature of chlorite formation in 
quartz-bearing rocks over a large range of temperature conditions. Vidal et al. (2006) claimed that the proportion of $\mathrm{Fe}^{3+}$ in chlorite could be estimated from a criterion based on the convergence of two Chl-Qtz- $\mathrm{H}_{2} \mathrm{O}$ equilibria that are compositionally dependant but assumed to be thermodynamically independent. The same authors and also de Andrade et al. (2011), Ganne et al. (2012), Lanari et al. (2012, 2013, 2014), Yamato et al. (2007), Grosch et al. (2014) and Trincal et al. (2015) showed that maps of chlorite crystallization temperature can be computed at the thin-section scale, and their superposition on microstructures allows one to discuss the $T$-deformation history of metapelitic samples. Application to low-grade metamorphic rocks indicates that temperatures as low as $100^{\circ} \mathrm{C}$ could be calculated, which suggests that the thermodynamic approach could, potentially, be used at very low- $T$ conditions. Finally, Inoue et al. (2009), Bourdelle et al. (2013a) and Lanari et al. (2014) used different compilations of natural samples to derive semiempirical equations that also link the composition of chlorite with its temperature of formation. The main difference compared to the thermodynamic approach is a simplification of the Gibbs' free energy equation, activity models and assumptions regarding chlorite $\mathrm{Fe}^{3+}$ content. These semi-empirical thermometers have the advantage of being easier to use than full thermodynamic modelling and they have been proved to reproduce successfully temperatures estimated independently in low-temperature series. However, only Lanari et al. (2014) verified the consistency of the semi-empirical equations with the existing experimental data and with natural compositions of chlorite in metamorphic rocks.

The purpose of the present study was to give an overview of the advantages and pitfalls of the different approaches mentioned above, and to discuss the potential of thermodynamic approaches developed by Vidal et al. (2001, 2005, 2006) and Lanari et al. (2014) for metamorphic rocks to very low-grade conditions. Particular emphasis is placed on the role of $\mathrm{Fe}^{3+}$ and its evolution with temperature, pressure and oxygen activity. To this end, preliminary thermodynamic data of a new chlorite $\mathrm{Fe}^{3+}$-bearing end-member (ferrisudoite) have been constrained.

\section{RANGE OF CHLORITE}

\section{COMPOSITION, RELEVANT END-} MEMBER COMPOSITIONS AND EQUILIBRIA

Many studies dealing with the variation of chlorite composition with intensive parameters and bulk-rock composition have already been published (see e.g.

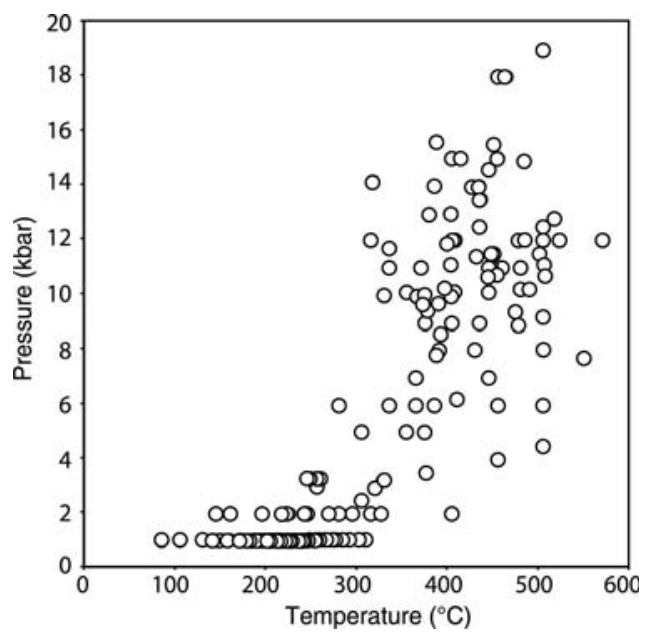

FIg. 1. Pressure and temperature conditions of the samples used in the present study

Curtis et al., 1985; Walshe, 1986; Wiewióra \& Weiss 1990; Hillier \& Velde, 1991; Vidal et al., 2001; Inoue et al., 2009; Bourdelle et al., 2013a, b; Lanari et al., 2014; Bourdelle \& Cathelineau, 2015 and references therein), and the results will not be repeated extensively here. Vidal et al. (2001) and Lanari et al. (2014) restricted their analysis to chlorites with $\mathrm{Si}<3$ a.p.f.u., which are the most common compositions in metapelites, and they compiled a reference set of $\sim 300$ analyses from samples covering a wide range of temperature $(T)$ and pressure $(P)$ (Fig. 1). In the present study, this compilation was complemented by 475 analyses from the literature and 700 analyses used by Grosch et al. (2012). From their original set of analyses, Vidal et al. (2001) and Lanari et al. (2014) showed that the compositional variability of chlorites result from three main substitutions Fe-Mg (FM), Tschermak (TK): Si $(\mathrm{Fe}, \mathrm{Mg})=\mathrm{Al}^{\mathrm{IV}} \mathrm{Al}^{\mathrm{VI}}$ and di/trioctahedral: $3\left(\mathrm{Mg}, \mathrm{Fe}^{2+}\right)=$ $2 \mathrm{Al}^{\mathrm{VI}} \square$ substitutions between the tri/tri-octahedral Sirich end-members clinochlore (Clin) and daphnite (Daph), the tri/tri-octahedral Al-rich end-members Feamesite (Fe-Am) and Mg-amesite (Mg-Am), and the di/ tri-octahedral end-members Fe-sudoite (Fe-Sud) and Mg-sudoite (Mg-Sud) (Fig. 2). In addition to these three main substitutions, several studies have shown that the incorporation of ferric iron in chlorite can be significant in a low-grade context (see e.g. Inoue et al., 2009 and references therein; Munoz et al., 2013). This incorporation results from the $\mathrm{Al}^{3+}=\mathrm{Fe}^{3+}$ and/or di-trioctahedral substitution $3\left(\mathrm{Fe}^{2+}, \mathrm{Mg}^{2+}\right)=\square 2 \mathrm{Fe}^{3+} \quad$ (Trincal and Lanari, 2016, this issue). Walshe (1986) suggested that 
the incorporation of ferric iron might also result from the exchange $\mathrm{Fe}^{2+}+\mathrm{OH}^{-}=\mathrm{Fe}^{3+}+\mathrm{O}^{2-}$ but to our knowledge, this exchange has not been confirmed thus far by analytical data.

In the absence of any experimental data on the magnitude of such substitutions with $P, T$ and $f_{\mathrm{O}_{2}}$, no thermodynamic properties of an $\mathrm{Fe}^{3+}$-bearing chlorite end-member are available yet in the existing internally consistent databases from Holland \& Powell (1998) or Berman (1988). Nevertheless, Vidal et al. $(2005,2006)$ proposed an estimate of the magnitude of $\mathrm{Fe}^{3+}$ of natural chlorites using a criterion based on the convergence of two independent equilibria that can be written with the end-members used to compute Fig. 2. This point is discussed in more detail in the next section.

For any chlorite formed in quartz-bearing rocks and occurring within the grey area in Fig. 2, at least two equilibria can be written which correspond to the intersection of the tie lines Clin or Daph-Sud and Am-Qtz:

$$
\begin{aligned}
2 \mathrm{Clin}+3 \mathrm{Mg}-\mathrm{Sud}= & 4 \mathrm{Mg}-\mathrm{Am}+7 \mathrm{Qtz} \\
& +4 \mathrm{H}_{2} \mathrm{O} \\
2 \mathrm{Daph}+3 \mathrm{Fe}-\mathrm{Sud}= & 4 \mathrm{Fe}-\mathrm{Am}+7 \mathrm{Qtz} \\
& +4 \mathrm{H}_{2} \mathrm{O}
\end{aligned}
$$

Similar equilibria can be written for chlorite in diaspore- (Dsp) or corundum- (Co) bearing rocks:

$$
\begin{gathered}
\mathrm{Clin}+\mathrm{Dsp} / \mathrm{Co}=\mathrm{Mg}-\mathrm{Am}+\mathrm{Mg}-\mathrm{Sud}+\mathrm{H}_{2} \mathrm{O} \\
\text { Daph }+ \text { Dsp } / \mathrm{Co}=\mathrm{Fe}-\mathrm{Am}+\mathrm{Fe}-\mathrm{Sud}+\mathrm{H}_{2} \mathrm{O}
\end{gathered}
$$

For any chlorite composition, equilibria 1 and 2 or 3 and 4 are achieved simultaneously at the $P$ and $T$ conditions of equilibrium.

In the presence of quartz and pure water, the condition of equilibrium 1 and 2 reads:

$$
\begin{aligned}
& \Delta G^{\circ P, T}(1) \\
= & \mathrm{R} T \ln \left(a(\mathrm{Mg}-\mathrm{Am})^{4} \cdot a(\mathrm{Clin})^{-2} \cdot a(\mathrm{Mg}-\mathrm{Sud})^{-3}\right) \\
& \Delta \mathrm{G}^{\circ P, T}(2) \\
= & \mathrm{R} T \ln \left(\mathrm{a}(\mathrm{Fe}-\mathrm{Am})^{4} \cdot \mathrm{a}(\mathrm{Daph})^{-2} \cdot \mathrm{a}(\mathrm{Fe}-\mathrm{Sud})^{-3}\right)
\end{aligned}
$$

where ' $a$ ' and $\Delta G^{\circ P, T}$ stand for the activity of endmembers in chlorite and for the variation in the Gibbs free energy of reaction for pure end-members, respectively. Different combinations of activities can lead to the same activity ratio (equilibrium constant) in equations 5 and 6 . Consequently, the same equilibrium constant and equilibrium temperature can be obtained with chlorite of different compositions and different $\mathrm{Al}^{\mathrm{IV}}$ or vacancy content crystallizing at the same $P-T$ conditions in rocks of different bulk compositions.

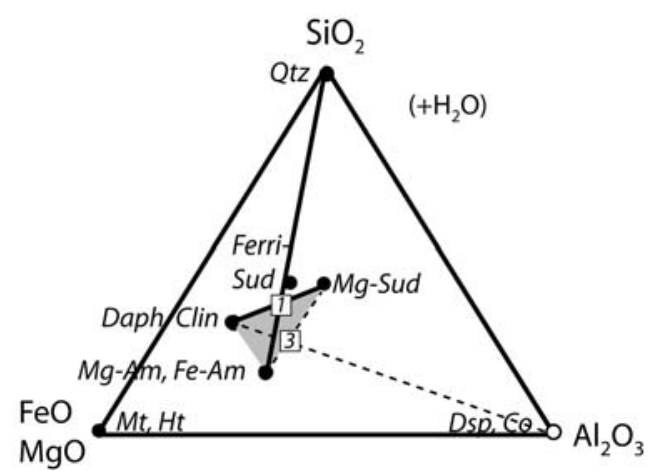

FIG. 2. Composition of the end-members and range of chlorite composition (grey area) considered in the present study plotted in a $\mathrm{SiO}_{2}-\mathrm{FeO}+\mathrm{MgO}-\mathrm{Al}_{2} \mathrm{O}_{3}$ ternary diagram. The intersection of the continuous and dashed lines corresponds to reactions 1 and 3 listed in the text.

Conversely, chlorite with the same $\mathrm{Al}^{\mathrm{IV}}$ or vacancy content can eventually form at different temperatures. For these reasons, empirical thermometers based on the sole $\mathrm{Al}^{\mathrm{IV}}$ or vacancy content cannot be used for wideranging rock compositions. Thermometers involving a ratio of end-member activities or proportions are the only valid equations when dealing with chlorites from rocks of contrasted compositions. With rising temperature and for a fixed chlorite composition, equilibria 1 to 4 are shifted from the left-hand side (LHS) containing the hydrated assemblage to the right-hand side (RHS) containing the dehydrated assemblage and free water. In order to maintain equilibrium with increasing temperature, the activity of the RHS end-members increases at the expense of that of the LHS end-members. The aluminous end-members $\mathrm{Mg}-\mathrm{Am}$ and $\mathrm{Fe}-\mathrm{Am}$ are located in the RHS of equilibria 1 to 4 so that their activity - and therefore the amount of $\mathrm{Al}^{\mathrm{IV}}$ and $\mathrm{Al}^{\mathrm{VI}}$ in chlorite equilibrated with quartz or Dsp/Co - is expected to increase with temperature and pressure. Similarly, the amount of vacancy (Mg- and Fe-Sud in the LHS of equilibria 1 and 2) and Si (Sud, Clin and Daph in the LHS) in chlorite equilibrated with quartz decreases with temperature. The same conclusion is drawn from inspection of the following equilibria written with the thermodynamic components used by Walshe (1986):

$$
\begin{aligned}
& 3 \mathrm{Si}_{4} \mathrm{Al}_{4} \square_{2} \mathrm{O}_{10}(\mathrm{OH})_{8}+5 \mathrm{Si}_{4} \mathrm{Mg}_{6} \mathrm{O}_{10}(\mathrm{OH})_{8} \\
& =6 \mathrm{Clin}+14 \mathrm{Qtz}+8 \mathrm{H}_{2} \mathrm{O}
\end{aligned}
$$

The vacancy-bearing and Si-rich end-members are also located in the LHS of equilibrium 7, which suggests 
that the amount of vacancies and $\mathrm{Si}$ in chlorite decreases with increasing temperature. In contrast, equilibria 3 and 4 indicate that the amount of vacancies in chlorite equilibrated with Dsp/Co increases with temperature.

In low-pressure rocks such as those used to calibrate the various $\mathrm{Al}^{\mathrm{IV}}$ empirical thermometers published to date, the effect of pressure is negligible compared to that of temperature and the variation of $\mathrm{Al}^{\mathrm{IV}}$ is a good proxy for temperature. This is not true for highpressure, low-temperature chlorite crystallizing at conditions typical of subduction zones. In such a setting, the effect of pressure on the equilibrium temperature of equilibria 1 and 2 cannot be further ignored, and high-pressure chlorites can have vacancies and $\mathrm{Al}$ contents similar to chlorite crystallizing at much lower temperature and pressure conditions. This point is illustrated in Fig. 3, which shows the $T$ and $P$ dependence of chlorite composition inferred from the natural data of Lanari et al. (2014). At $P<4 \mathrm{kbar}$ and $T$ $<300^{\circ} \mathrm{C}$, the amount of $\mathrm{Al}$ on $\mathrm{M} 1$ (amesite content) increases almost linearly with temperature (Fig. 3a), which is consistent with the empirical $\mathrm{Al}^{\mathrm{IV}}-T$ empirical equations published to date. At higher $P$ and $T$, the amount of amesite in chlorite does not follow the trend observed at low temperature because it is also controlled by pressure. Thus the large scatter of amesite content vs. $T$ in Fig. 3 a at $P>6$ kbar reflects the variability of the $T / P$ conditions among the different samples. A similar observation is made for the vacancy- $T$ evolution (Fig. 3b), which defines different trends for the low-pressure and medium- to high-pressure samples. Finally, Fig. $3 \mathrm{c}$ shows that the $\mathrm{Fe} / \mathrm{Mg}$ ratio of chlorite (considering $\mathrm{Fe}_{T}=\mathrm{Fe}^{2+}$ ) does not show any consistent relationship with $T$ and $P$. This ratio is controlled primarily by the bulk-rock composition and the $\mathrm{Fe} / \mathrm{Mg}$ correction introduced in empirical $\mathrm{Al}^{\mathrm{IV}}$ thermometers does not seem to be supported, either for theoretical reasons, or by observations when considering large sets of natural data.

\section{MODELLING THE CONDITIONS OF CHLORITE FORMATION AND FE ${ }^{3+}$ CONTENT}

The discussion above offers a theoretical background for the evolution of $\mathrm{Al}^{\mathrm{IV}}$ and vacancy contents with temperature that has been documented by many authors in the past. It suggests that empirical thermometers based on the sole variation of $\mathrm{Al}^{\mathrm{IV}}$ or vacancy content cannot be extrapolated outside the range of $P$ conditions and bulk-rock composition at which they were calibrated. This explains why a myriad of different equations have been published in the past; they were derived from different sets of natural samples.

As an alternative approach to the empirical thermometers, the temperature condition of chlorite formation can be estimated from the thermodynamic calculation of equilibria similar to those listed above (1-4). This requires knowledge of the standard-state thermodynamic properties of the relevant end-members and activity-composition models. Walshe (1986) proposed the first chlorite model which was able to estimate the formation temperature, ferric iron and water contents of chlorite coexisting with quartz and water at known or assumed pressure. The composition of chlorite was represented by six independent thermodynamic components $\mathrm{Si}_{4} \mathrm{Mg}_{6} \mathrm{O}_{10}(\mathrm{OH})_{8}$, Clin, Daph, $\mathrm{Si}_{3} \mathrm{Al}_{2}\left(\mathrm{Fe}^{2+}\right)_{5}$ $\mathrm{O}_{10}(\mathrm{OH})_{8}, \quad \mathrm{Si}_{4} \mathrm{Al}_{4} \mathrm{O}_{10}(\mathrm{OH})_{8}$ and $\quad \mathrm{Si}_{3} \mathrm{Al}_{2}\left(\mathrm{Fe}^{2+}\right)_{4} \mathrm{Fe}^{3+}$
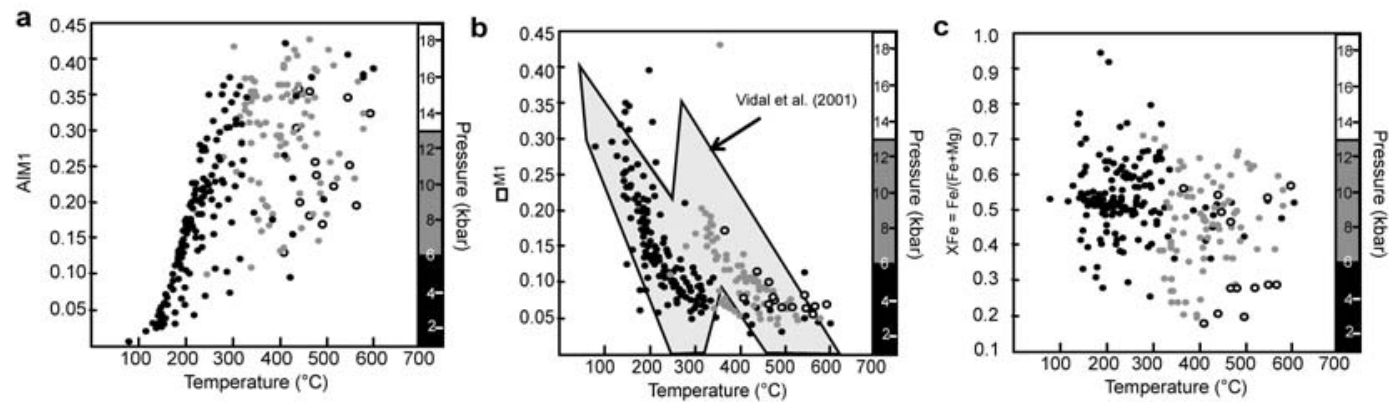

FIG. 3. Al on M1 (a), vacancy on M1 (b) and XFe of chlorite (c) as a function of temperature and pressure (after Lanari et al., 2014) assuming that $\mathrm{Fe}_{\text {Total }}=\mathrm{Fe}^{2+}$. AlM1 and $\square \mathrm{M} 1$ are proportional to the amount of amesite and sudoite endmembers respectively (AlM1 $=1$ for pure amesite, $\square \mathrm{M} 1=1$ for pure sudoite, AlM1 $=\square \mathrm{M} 1=0$ for amesite-free and sudoite-free chlorite). The grey area in part b encompasses the vacancy contents reported by Vidal et al. (2001). 
$\mathrm{O}_{11}(\mathrm{OH})_{7}$, which can be used to write four chloritequartz-water equilibria (two independent). This model was not used in the present contribution because the standard-state and solid-solution thermodynamic properties were not constrained by experimental data and they are not compatible with the existing internally consistent databases. Two kinds of thermodynamic models compatible with the existing internally consistent databases of Holland \& Powell (1998) or Berman (1988) have been proposed so far; they have different philosophies and assumptions:

(1) Vidal et al. $(2001,2006)$ considered a cation repartition on two tetrahedral sites $\mathrm{T} 1(\mathrm{Si}, \mathrm{Si})_{2}$ and $\mathrm{T} 2$ $(\mathrm{Si}, \mathrm{Al})_{2}$ and three octahedral sites $\mathrm{M} 1\left(\square, \mathrm{Al}, \mathrm{Fe}^{2+}, \mathrm{Mg}^{2+}\right)_{1}$, $\mathrm{M} 2-3\left(\mathrm{Mg}^{2+}, \mathrm{Fe}^{2+}, \mathrm{Al}\right)_{4}$ and $\mathrm{M} 4\left(\mathrm{Al}, \mathrm{Fe}^{3+}\right)_{1}$, and assumed equipartition of $\mathrm{Fe}$ and $\mathrm{Mg}$ on $\mathrm{M} 2-\mathrm{M} 3$ and $\mathrm{M} 1$. The conditions of chlorite formation in the presence of quartz and $\mathrm{H}_{2} \mathrm{O}$ are calculated using four equilibria involving five chlorite end-members (Clin, Daph, Fe-Am, Mg-Am and Mg-Sud):

$$
\begin{aligned}
2 \mathrm{Clin}+3 \mathrm{Mg}-\mathrm{Sud}= & 4 \mathrm{Mg}-\mathrm{Am}+7 \mathrm{Qtz} \\
& +4 \mathrm{H}_{2} \mathrm{O}
\end{aligned}
$$

$$
4 \mathrm{Clin}+5 \mathrm{Fe}-\mathrm{Am}=4 \mathrm{Daph}+5 \mathrm{Mg}-\mathrm{Am}
$$

$16 \mathrm{Daph}+15 \mathrm{Mg}-\mathrm{Sud}=20 \mathrm{Fe}-\mathrm{Am}+6 \mathrm{Clin}$

$$
+35 \mathrm{Qtz}+20 \mathrm{H}_{2} \mathrm{O}
$$

$4 \mathrm{Daph}+6 \mathrm{Mg}-\mathrm{Sud}=5 \mathrm{Fe}-\mathrm{Am}+3 \mathrm{Mg}-\mathrm{Am}$

$$
+14 \mathrm{Qtz}+8 \mathrm{H}_{2} \mathrm{O}
$$

The thermodynamic properties and non-ideal mixing properties (Table 1) are believed to be compatible with the internally consistent thermodynamic database of Berman (1988). The properties of Clin, Mg-Am, MgSud and the WAl-Mg Margules parameter were constrained by experimental data gathered in the $\mathrm{MgO}-\mathrm{Al}_{2} \mathrm{O}_{3}-\mathrm{SiO}_{2}-\mathrm{H}_{2} \mathrm{O}$ chemical system, and those of Daph and Fe-Ames and WAl-Fe were constrained independently by experimental data obtained in the $\mathrm{FeO}-\mathrm{Al}_{2} \mathrm{O}_{3}-\mathrm{SiO}_{2}-\mathrm{H}_{2} \mathrm{O}$ (FASH) system (Fig. 4). This approach leads to contrasted values of WAl-Fe $\left(-10.6 \mathrm{~kJ}\right.$ at $\left.300^{\circ} \mathrm{C}, 5 \mathrm{kbar}\right)$ and WAl-Mg $(+6.8 \mathrm{~kJ}$ at $300^{\circ} \mathrm{C}, 5 \mathrm{kbar}$ ), which seems unlikely in view of the similar ionic potential of $\mathrm{Fe}^{2+}$ and $\mathrm{Mg}^{2+}$. However, attempts to resolve this problem while maintaining a good fit of the experimental constraints in MASH and in FASH proved unsuccessful. For the cation repartition used by Vidal et al. (2005, 2006), the endmembers Clin, Daph, Mg-Am and Fe-Am are independent because the site M1 is filled either by $\mathrm{Mg}$ in the case of Clin or Fe in the case of Daph.
Equilibrium 8 corresponds, thus, to the intracrystalline exchange reaction $\mathrm{MgM} 1\left(\mathrm{Fe}_{5} \mathrm{Mg}_{4}\right) \mathrm{M} 4=\mathrm{FeM} 1$ $\left(\mathrm{Mg}_{5} \mathrm{Fe}_{4}\right) \mathrm{M} 4$. This internal equilibrium is achieved at defined $P$ and $T$ conditions along a univariant line at fixed $\mathrm{Fe}^{3+}$ values. Two of the four equilibria $(1,8,9$ and 10) are independent, and the $P, T, X \mathrm{Fe}^{3+}$ conditions of chlorite + quartz + water equilibrium are defined by their intersection in a $P-T$ field. This approach allows one to estimate a minimum value of $X \mathrm{Fe}^{3+}=\mathrm{Fe}^{3+} / \mathrm{Fe}_{\text {Total }}$ required to obtain convergence of equilibria at assumed pressure. In view of the analytical uncertainties and unknown uncertainties of the thermodynamic properties of the chlorite end-members and non-ideal solidsolution parameters, a certain scatter between equilibria (1, 8, 9 and 10) is accepted. In the present study, convergence was assumed to be achieved when the temperature difference between equilibrium $8-$ the most sensitive to small variations of compositions - and the other three equilibria was $<30^{\circ} \mathrm{C}$. Equilibrium temperatures and $\left(X \mathrm{Fe}^{3+}\right) \mathrm{Chl}$ were calculated for all chlorite compositions at the pressure conditions reported in the original publications or at 1 to $2 \mathrm{kbar}$ for the low-temperature samples. Calculation was conducted starting from $X \mathrm{Fe}^{3+}=0$ and increasing the value by $1 \%$ until convergence was achieved. It is emphasized that convergence at lower temperature can be maintained with a further increase of $X \mathrm{Fe}^{3+}$. The estimated values of $X \mathrm{Fe}^{3+}$ discussed in the following are, therefore, minimum values at maximum temperatures. The effect of a further increase of $X \mathrm{Fe}^{3+}$ on equilibrium temperature is weak at low temperature, but it can be very significant at high temperature (see Grosch et al., 2012). Note also that the quantity of $\mathrm{Fe}$ considered as $\mathrm{Fe}^{3+}$ influences the activity of all chlorite end-members. Increasing $X \mathrm{Fe}^{3+}$ leads to an increase in vacancies in structural formulae calculated on a 14 anhydrous oxygen basis, so that even the activity of $\mathrm{Mg}$ Sud and the location of equilibrium 1 involving Fe-free end-members are affected.

(2) Lanari et al. (2014) considered a cation-site repartition identical to that adopted by Vidal et al. (2001, 2006) but they followed the formalism of Powell \& Holland (1999), which assumes that only three of the four end-members Mg-Ames, Fe-Am, Clin and Daph are independent. It follows that only one of equilibria $(1,8,9$ and 10) is independent. The temperature of chlorite formation is calculated from the location of equilibrium 1 with an assumption that $X \mathrm{Fe}^{3+}$ and the Gibbs free energy of the dependent endmember Fe-Am can be estimated with relationships between the $\mathrm{Mg}$ - and Fe-bearing end-members (see Lanari et al., 2014). Unfortunately, this approach does 
TABLE 1. Standard-state properties of chlorite end-members and Margules parameters of the chlorite solid solution (see Berman, 1988; Vidal et al., 2006 for the format).

\begin{tabular}{|c|c|c|c|c|}
\hline \multicolumn{5}{|c|}{ Mg-sudoite (Vidal et al., 1992, 2006) $\left.\left[\mathrm{Si}_{2}\right]_{\mathrm{T} 1}[\mathrm{Si}, \mathrm{Al}]_{\mathrm{T} 2}\right)^{\mathrm{IV}}\left([\square]_{\mathrm{M} 1}\left[\mathrm{Mg}_{2}, \mathrm{Al}_{2}\right]_{\mathrm{M} 2-}[\mathrm{Al}]_{\mathrm{M} 4}\right)^{\mathrm{VI}} \mathrm{O}_{10}(\mathrm{OH})_{8}$} \\
\hline ST & -8655273.0 & 390.50 & 20.510 & \\
\hline $\mathrm{C} 1$ & 1115.84 & -8507.5 & -19777440 & 2959147000 \\
\hline V1 & 2.64515406 & 0.0 & -0.18194707 & 0.0 \\
\hline \multicolumn{5}{|c|}{ Ferri-sudoite (present study) $\left.\left[\mathrm{Si}_{2}\right]_{\mathrm{T} 1}[\mathrm{Si}, \mathrm{Al}]_{\mathrm{T} 2}\right)^{\mathrm{IV}}\left([\square]_{\mathrm{M} 1}\left[\mathrm{Mg}_{2}, \mathrm{Al}_{2}\right]_{\mathrm{M} 2 \pm 3}\left[\mathrm{Fe}^{3+}\right]_{\mathrm{M} 4}\right)^{\mathrm{VI}} \mathrm{O}_{10}(\mathrm{OH})_{8}$} \\
\hline ST & $\begin{array}{l}-8221273^{\mathrm{a}} \\
-8230400^{\mathrm{b}}\end{array}$ & 405.50 & 20.400 & \\
\hline $\mathrm{C} 1$ & 1122.25 & -8569.5 & -17431790 & 2552588000 \\
\hline V1 & 2.64515406 & 0.0 & -0.18194707 & 0.0 \\
\hline \multicolumn{5}{|c|}{ Daphnite (Vidal et al., 2001, 2006) $\left.\left[\mathrm{Si}_{2}\right]_{\mathrm{T} 1}[\mathrm{Si}, \mathrm{Al}]_{\mathrm{T} 2}\right)^{\mathrm{IV}}\left(\left[\mathrm{Fe}^{2+}\right]_{\mathrm{M} 1}\left[\mathrm{Fe}_{4}^{2+}\right]_{\mathrm{M} 2 \pm 3}[\mathrm{Al}]_{\mathrm{M} 4}\right)^{\mathrm{VI}} \mathrm{O}_{10}(\mathrm{OH})_{8}$} \\
\hline $\mathrm{ST}$ & -7120845 & 559.40 & 21.600 & \\
\hline $\mathrm{C} 1$ & 1229.233 & -10256.5 & -12276900 & 2121510000 \\
\hline V1 & 2.64515406 & 0.0 & -0.18194707 & 0.0 \\
\hline \multicolumn{5}{|c|}{ Fe-amesite (Vidal et al., 2005, 2006) $\left.\left[\mathrm{Si}_{2}\right]_{\mathrm{T} 1}\left[\mathrm{Al}_{2}\right]_{\mathrm{T} 2}\right)^{\mathrm{IV}}\left([\mathrm{Al}]_{\mathrm{M} 1}\left[\mathrm{Fe}_{4}^{2+}\right]_{\mathrm{M} 2 \pm 3}[\mathrm{Al}]_{\mathrm{M} 4}\right)^{\mathrm{VI}} \mathrm{O}_{10}(\mathrm{OH})_{8}$} \\
\hline $\mathrm{ST}$ & -7607460.0 & 514.80 & 20.900 & \\
\hline $\mathrm{C} 1$ & 1219.81 & -10021.5 & -14439720 & 2392326000 \\
\hline V1 & 2.64515406 & 0.0 & -0.18194707 & 0.0 \\
\hline \multicolumn{5}{|c|}{ Clinochlore (Berman, 1988) $\left.\left[\mathrm{Si}_{2}\right]_{\mathrm{T} 1}[\mathrm{Si}, \mathrm{Al}]_{\mathrm{T} 2}\right)^{\mathrm{IV}}\left([\mathrm{Mg}]_{\mathrm{M} 1}\left[\mathrm{Mg}_{4}\right]_{\mathrm{M} 2 \pm 3}[\mathrm{Al}]_{\mathrm{M} 4}\right)^{\mathrm{VI}} \mathrm{O}_{10}(\mathrm{OH})_{8}$} \\
\hline ST & -8909589.84 & 435.15 & 21.147 & \\
\hline $\mathrm{C} 1$ & 1214.284 & -11217.13 & 0.000 & -1256253184 \\
\hline V1 & 2.64515406 & 0.0 & -0.18194707 & 0.0 \\
\hline \multicolumn{5}{|c|}{ Mg-amesite (Vidal et al., 2001, 2006) $\left.\left[\mathrm{Si}_{2}\right]_{\mathrm{T} 1}\left[\mathrm{Al}_{2}\right]_{\mathrm{T} 2}\right)^{\mathrm{IV}}\left([\mathrm{Al}]_{\mathrm{M} 1}\left[\mathrm{Mg}_{4}\right]_{\mathrm{M} 2 \pm 3}[\mathrm{Al}]_{\mathrm{M} 4}\right)^{\mathrm{VI}} \mathrm{O}_{10}(\mathrm{OH})_{8}$} \\
\hline $\mathrm{ST}$ & -9035900.5 & 403.20 & 20.520 & \\
\hline $\mathrm{C} 1$ & 1144.45 & -8327.2 & -20058040 & 2820786000 \\
\hline V1 & 2.64515406 & 0.0 & -0.18194707 & 0.0 \\
\hline \multicolumn{5}{|c|}{ Margules parameters on site M1 (Vidal et al., 2006) } \\
\hline WMg-Al & -9400 & -30 & -0.2 & \\
\hline $\mathrm{WMg}-\square$ & 10000 & -25 & 0.9 & \\
\hline WFe-Al & 1200 & 31 & 0.7 & \\
\hline WFe- $\square$ & 2000 & -15 & 0.4 & \\
\hline WA1- $\square$ & -10000 & -30 & 0.9 & \\
\hline
\end{tabular}

$\mathrm{ST}: \Delta H^{\circ} f(\mathrm{~J}), S^{\circ}(\mathrm{J} / \mathrm{K}), V^{\circ}(\mathrm{J} / \mathrm{b}) ; C \mathrm{p}: \mathrm{K} 0, \mathrm{~K} 1, \mathrm{~K} 2, \mathrm{~K} 3\left(C \mathrm{p}=\mathrm{K} 0+\mathrm{K} 1 / T^{-0.5}+\mathrm{K} 2 / T^{-2}+\mathrm{K} 3 / T^{-3}\right) ; V(P, T): V 1, V 2, V 3, V 4(V$ $\left.(P, T) / V(1,298)=1+V 1(T-298)+V 2(T-298)^{2}+V 3(\mathrm{P}-1)+V 4(P-1)^{2}\right)$.

${ }^{\mathrm{a}}$ estimated using equilibria 1 and $21-24 ;^{\mathrm{b}}$ estimated as $\left(\Delta H^{\circ} f(\mathrm{Mg}\right.$-sudoite $)-\Delta H^{\circ} f$ (corundum $) / 2+\Delta H^{\circ} f($ hematite $\left.) / 2\right)$. The Margules parameters list the $\mathrm{WH}, \mathrm{WS}$ and $\mathrm{Wv}$ values $(\mathrm{W}=\mathrm{WH}+\mathrm{T}(\mathrm{K}) * \mathrm{WS}+(\mathrm{P}-1) \mathrm{Wv})$.

not allow us to fit the experimental data of chlorite composition reported by Parra et al. (2005) in the FASH system (Fig. 4).

Whatever the thermodynamic model, at least one temperature of chlorite-quartz-water equilibrium can be calculated at fixed pressure with assumptions regarding the proportion of ferric iron in chlorite. This calculation involves evaluation of equilibrium constants expressed as a ratio of chlorite end-member activities and therefore cation proportions. It follows that chlorites of different compositions (and different $\mathrm{Al}^{\mathrm{IV}}$ contents) crystallizing at identical $P-T$ conditions but in rocks of different compositions can have identical equilibrium constants of (1) and (8) to (10). Inoue et al. (2009), Bourdelle et al. (2013a), and Lanari et al. (2014) proposed several semi-empirical chlorite thermometers also involving equilibrium constants calculated as the ratio of chlorite end-member activities. The main difference compared to the thermodynamic approach is a simplification of the Gibbs free energy equation, activity models and assumptions on the ferric iron content in chlorite. These semi-empirical thermometers are easy to use and they are believed to reproduce successfully temperatures estimated independently in 

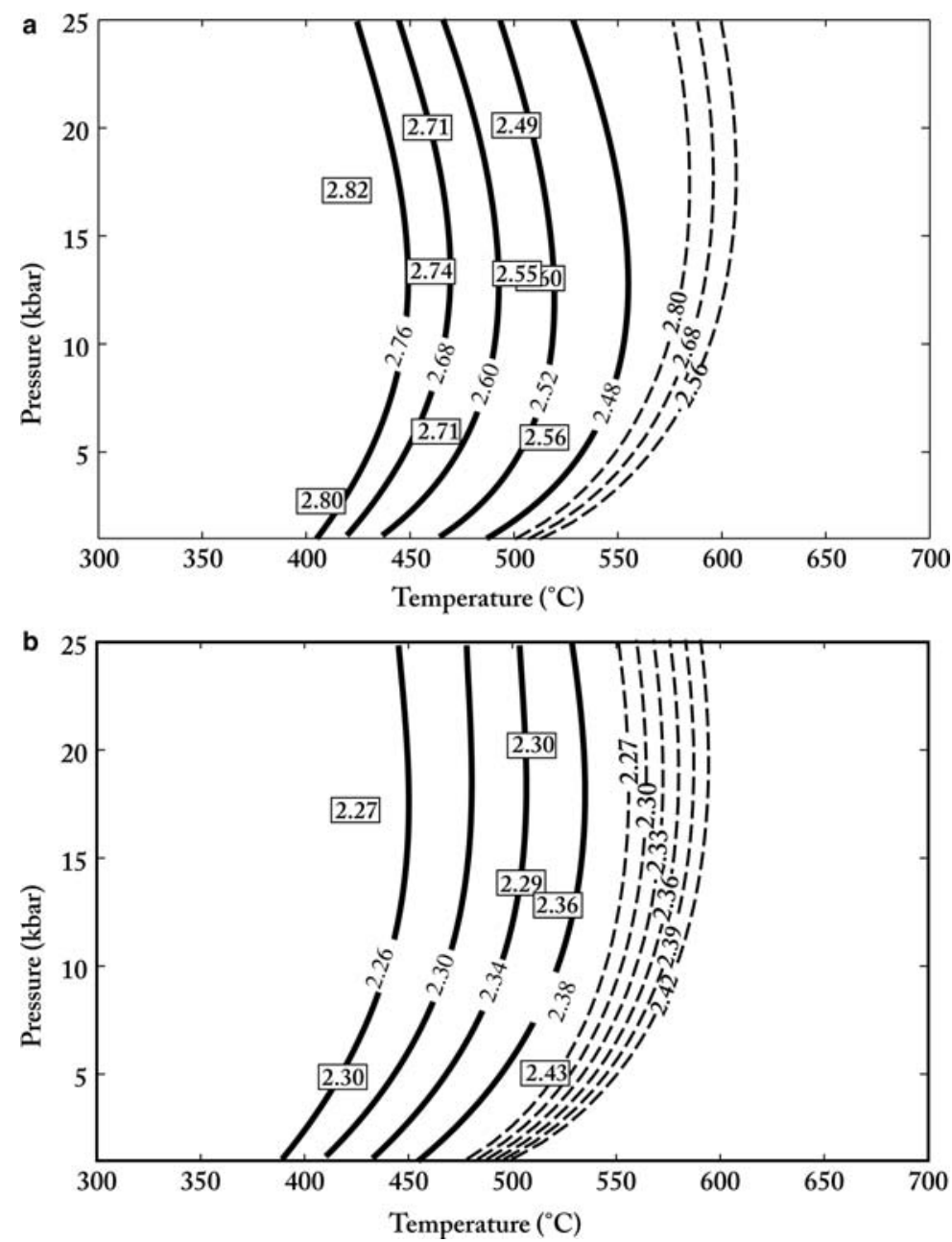

FIG. 4. Comparison of measured and calculated Si content of chlorite in the FASH system with almandine and fayalite (a) or chloritoid and hercynite (b). Boxes: experimental data of Parra et al. (2005); continuous lines: Si content calculated with the thermodynamic properties of Fe-amesite and daphnite and the solid solution model of Vidal et al. $(2005,2006)$; dashed lines: Si content calculated with the Holland et al. (1998) model updated by Coggon \& Holland (2002), which assumes that the thermodynamic properties of Fe-Am depend on those of Clin, Mg-Am and Daph.

low-temperature series (Inoue et al., 2009; Bourdelle et al., 2013a; Lanari et al., 2014) and metamorphic rocks (Lanari et al., 2014). The weakness of the semiempirical equations is that their compatibility with experimental data obtained in MASH and FASH systems has not always been checked, and they are restricted to quartz-bearing rocks.

Finally, the main difference between the thermodynamic approach of Vidal et al. $(2005,2006)$ and those of Vidal et al. (2001), Lanari et al. (2014) or the semi-empirical thermometers of Inoue et al. (2009),
Bourdelle et al. (2013a) and Lanari et al. (2014) is that the former leads to the estimation of $T-\left(X \mathrm{Fe}^{3+}\right) \mathrm{Chl}$ pairs at given pressure whereas the latter estimate $T$ at assumed or measured $X \mathrm{Fe}^{3+}$ and pressure, or assuming a negligible role of pressure. This last assumption is acceptable at low-pressure conditions but becomes problematic for metamorphic samples because the amount of $\mathrm{Mg}$-Sud end-member at fixed temperature has been shown to increase with pressure (Fig. 3b).

A comparison of the approaches of Vidal et al. (2006), Lanari et al. (2014) and Inoue et al. (2009) is 
shown in Fig. 5, which reports temperatures estimated for the set of 1541 analyses used in the present study. The temperatures calculated with the assumption $\mathrm{Fe}^{3+}$ $=0$ (equation 38 of Lanari et al., 2014) or $\mathrm{Fe}^{3+}>0$ (all other approaches) are labelled $\mathrm{TFe}^{2+}$ and $\mathrm{TFe}^{3+}$, respectively, in Fig. 5 and in the following. All calculations were conducted with a MATLAB script with a GUI interface available on request from the first author.

The temperature conditions estimated for blueschistfacies metamorphic samples with the approach of Vidal et al. (2006) $\left(T \mathrm{Fe}^{3+}\right.$ Vidal) cover a wide range of temperature from 275 to $550^{\circ} \mathrm{C}$ (Fig. 5a). About one third of the samples show temperatures of $<350^{\circ} \mathrm{C}$, which is $50-100^{\circ} \mathrm{C}$ lower than the published peak temperatures derived for the samples studied. Using the $X \mathrm{Fe}^{3+}$ estimated with the Vidal et al. (2006) approach, the temperatures estimated with the semiempirical equations of Inoue et al. (2009) $\left(\mathrm{TFe}^{3+}\right.$ Inoue) or Lanari et al. (2014) $\left(T \mathrm{Fe}^{3+}\right.$ Lanari) show a similar evolution but the estimated temperatures are $50-100^{\circ} \mathrm{C}$ lower in the case of Inoue et al. (2009) and higher in the case of Lanari et al. (2014). The most important deviation is observed between $T \mathrm{Fe}^{2+}$ Lanari and the other temperature estimates. A significant proportion of chlorites calculated to have crystallized at $\mathrm{TFe}^{3+} \approx 300^{\circ} \mathrm{C}$ give much higher $T \mathrm{Fe}^{2+}$ Lanari $\left(>500^{\circ} \mathrm{C}\right.$, open symbols in Fig. 5a) and plot on a different trend. The same observation is made for the Barberton samples from Grosch et al. (2012) (Fig. 5c). In both cases, the maximum $T \mathrm{Fe}^{2+}$ Lanari can be as high as $900^{\circ} \mathrm{C}$, but the highest temperatures are obtained for samples containing very small amounts of vacancies $(<0.05$ p.f.u., open circles below the dashed line in the temperature-vacancy plot shown in Fig. 5a). The MgSud activity and temperatures derived from these analyses are very sensitive to small variations in composition and $\mathrm{Fe}^{3+}$-content, and they should not be used for reliable thermometric estimates. In contrast, Fig. $5 \mathrm{~b}$ shows that similar temperatures are estimated with all approaches for low-pressure and low-grade samples.

This comparison indicates that similar results are obtained with all methods at $T<300^{\circ} \mathrm{C}$, and similar trends are observed at higher temperature for the three methods allowing the incorporation of $\mathrm{Fe}^{3+}$, although with a significant scatter at $T>400^{\circ} \mathrm{C}$. With the $X \mathrm{Fe}^{3+}$ values derived using the Vidal et al. (2006) approach, $T \mathrm{Fe}^{3+}$ Vidal and $T \mathrm{Fe}^{3+}$ Inoue are quite consistent. However, the highest $\mathrm{TFe}^{3+}$ Inoue estimated for blueschist metamorphic samples are lower whereas $\mathrm{TFe}^{3+}$ Lanari are higher. In all approaches, the temperature calculated depends heavily on the sudoite activity, which is proportional to the amount of vacancy in chlorite $\left(a(\mathrm{Sud})=64 *(X \mathrm{Si} * X \mathrm{Al}) T_{2} *\right.$ $\left.\left.X \square \mathrm{M}_{1} *(X \mathrm{Mg})^{2} \mathrm{M}_{2-3} *(X \mathrm{Al})^{2} \mathrm{M}_{2-3} *(X \mathrm{Al}) \mathrm{M}_{4}\right)\right)$. This is illustrated in Fig. 5, which shows that the amount of vacancy in chlorite increases with a drop in temperature. As noted by Laird (1988), the amount of vacancy in chlorite structural formulae calculated on a charge-normalized 14 anhydrous-oxygen basis increases with increasing $X \mathrm{Fe}^{3+}$. It is therefore not surprising that like vacancies, $X \mathrm{Fe}^{3+}$ increases with reducing temperature. This trend is illustrated in Fig. 6, where the $T \mathrm{Fe}^{3+}$ Vidal vs. $X \mathrm{Fe}^{3+}$ values of samples used to compute Fig. 5 have been plotted. Figure 6 also indicates that larger $X \mathrm{Fe}^{3+}$ values are calculated for the high-pressure samples than for the low-pressure samples. Nevertheless, vacancies are also noted to increase with reducing $T$ under the assumption that $\mathrm{Fe}^{2+}$ $=\mathrm{Fe}_{\text {Total }}$ (see Fig. $3 \mathrm{~b}$ and the open circles in Fig. 5a,b). Therefore, the increase in vacancies with reducing temperature is not just a mathematical artefact resulting from the calculation of $\mathrm{Fe}^{3+}$-bearing structural formulae on a 14-oxygen basis. Interestingly, even at low temperature, where $X \mathrm{Fe}^{3+}$ calculated with the Vidal et al. (2006) approach is at a maximum, $T \mathrm{Fe}^{2+}$ Lanari is similar to the three $T \mathrm{Fe}^{3+}$ (Fig. 5b). This indicates that the $T \mathrm{Fe}^{2+}$ Lanari equation includes the systematic variation of $X \mathrm{Fe}^{3+}$ with temperature observed in Fig. 6, which explains why similar $T \mathrm{Fe}^{2+}$ and $T \mathrm{Fe}^{3+}$ are obtained at low $T$ and $P$ (Fig. 5b) for contrasting amounts of vacancies and ferric iron contents. Nevertheless, it is evident from Fig. 5a,c that the $X \mathrm{Fe}^{3}$ ${ }^{+} v s$. temperature relationship that was used to derive the $T \mathrm{Fe}^{2+}$ Lanari equation is not fully consistent with the $T$ $X \mathrm{Fe}^{3+}$ relationship obtained with the thermodynamic approach of Vidal et al. (2006). This is illustrated by the divergence between $T \mathrm{Fe}^{2+}$ Lanari and the three $T \mathrm{Fe}^{3+}$ calculated for the low-pressure Barberton samples (Fig. 5c) and several HP samples Fig. 5a.

\section{COMPARISON OF ESTIMATED AND MEASURED $\left(X \mathrm{FE}^{3+}\right) \mathrm{CHL}$}

At this stage, we can only conclude from the comparison of $\mathrm{TFe}^{2+}$ and $T \mathrm{Fe}^{3+}$ in Fig. 5a,c that either some $X \mathrm{Fe}^{3+}$ values derived with the Vidal et al. (2006) approach are overestimated and the low $T \mathrm{Fe}^{3+}$ obtained for some HP-HT samples are underestimated, or that $T \mathrm{Fe}^{2+}$ Lanari only pertains for $f_{\mathrm{O}_{2}}$ conditions buffered by specific assemblages. An overestimation of $X \mathrm{Fe}^{3+}$ due to errors in the standard-state thermodynamic properties and the non-ideal Margules 

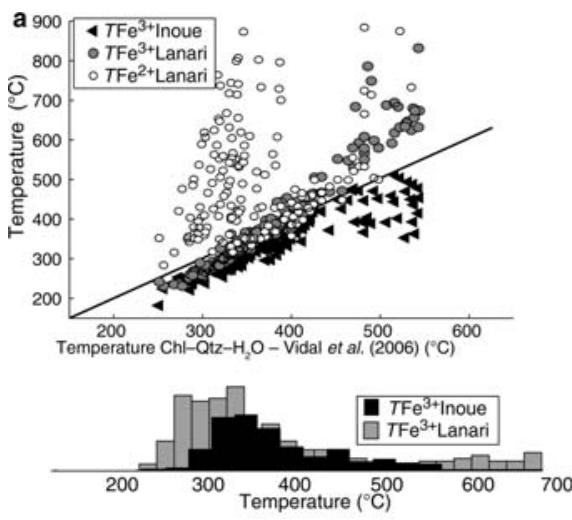

b
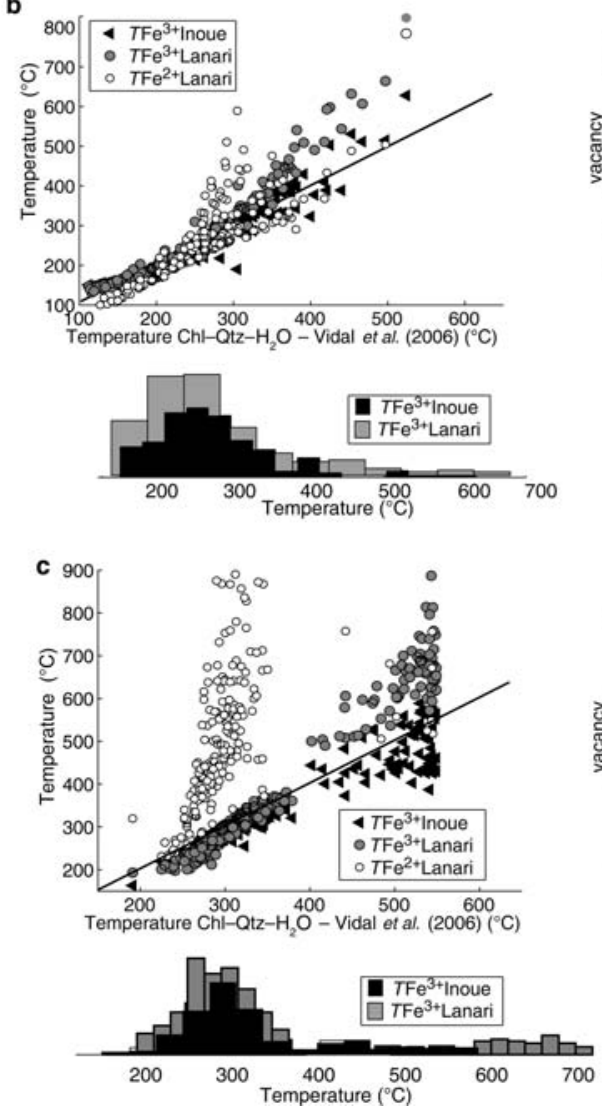
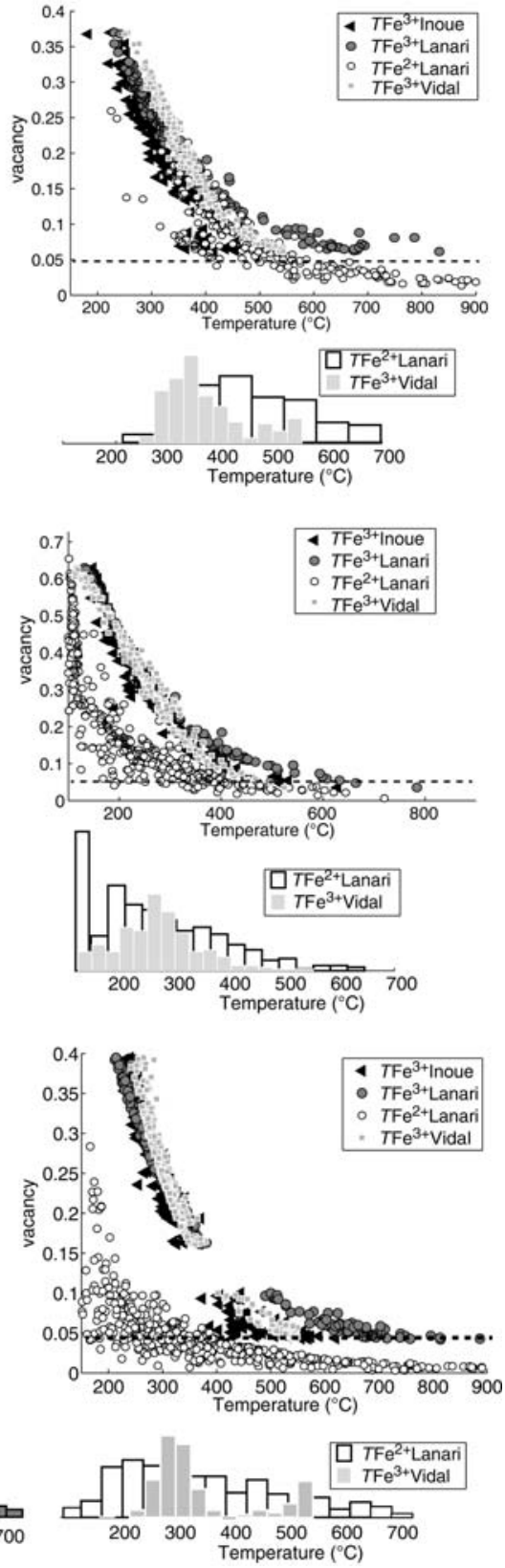

FIG. 5. Left: Plot of temperatures estimated with equations $38\left(T \mathrm{Fe}^{3+}\right.$ Lanari) and $40\left(T \mathrm{Fe}^{2+}\right.$ Lanari) of Lanari et al. (2014) and with the thermometer of Inoue et al. (2009) ( $\left(\mathrm{Fe}^{3+}\right.$ Inoue) $v s$. temperatures estimated using the approach of Vidal et al. (2006). $T \mathrm{Fe}^{3+}$ Lanari and $T \mathrm{Fe}^{3+}$ Inoue were calculated using the $X \mathrm{Fe}^{3+}$ values obtained with the approach of Vidal et al. (2006), and $T \mathrm{Fe}^{2+}$ Lanari assuming $X \mathrm{Fe}^{3+}=0$. Right: Plot of vacancy content $v s$. estimated temperatures: (a) and (b) are high-pressure ( $>6 \mathrm{kbar}$ ) and low- to medium-pressure ( $<6 \mathrm{kbar})$, respectively; (c) shows the results obtained for the low-pressure samples of Grosch et al. (2012). The unrealistically high $T \mathrm{Fe}^{2+}$ Lanari are obtained for chlorites with $<0.05$ vacancy p.f.u. (dashed line in the vacancy-temperature plots). The histograms show the repartition of temperatures estimated with the different approaches. 


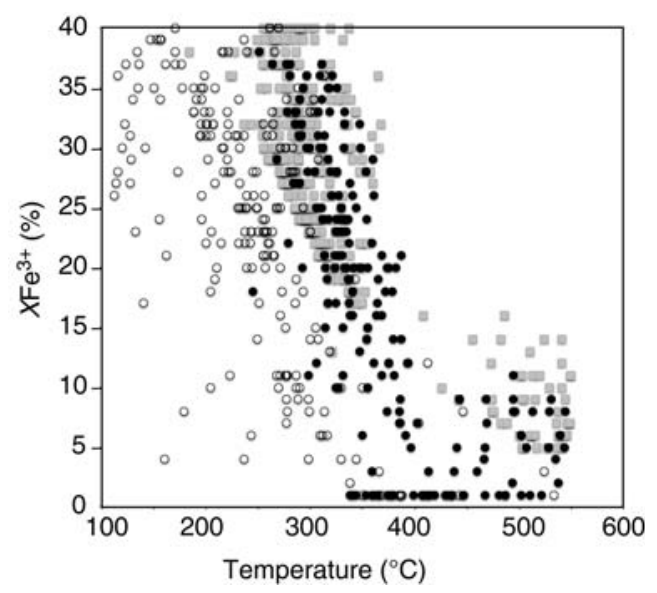

FIG. 6. Estimated $T \mathrm{Fe}^{3+}$ Vidal and $X \mathrm{Fe}^{3+}$ pairs for low- and medium-pressure samples (open circles), high-pressure samples (black circles) and the samples from Grosch et al.

(2012) (grey squares). parameters of Vidal et al. (2006) is possible, but this should be demonstrated by a systematic comparison of measured and estimated $X \mathrm{Fe}^{3+}$ from natural samples covering a wide range of $P, T$ and $f_{\mathrm{O}_{2}}$ conditions. Such a study is still lacking, but a firstorder comparison of measured and estimated $X \mathrm{Fe}^{3+}$ contents for samples of known temperature of crystallization is shown in Fig. 7 which was obtained for the Rouez, Niger and Saint-Martin low- $T$ samples compiled by Inoue et al. (2009), the Glarus sample of Bourdelle et al. (2013c) and a blueschist-facies sample retrogressed into the greeschist facies from Sambagawa (de Andrade et al., 2006; Munoz et al., 2006; Vidal et al., 2006). T-X $\mathrm{Fe}^{3+}$ values were calculated at $2 \mathrm{kbar}$ except for the Sambagawa sample, for which calculations were made at 2, 5 and $10 \mathrm{kbar}$ for the low-, medium- and high-temperature chlorite groups identified by de Andrade et al. (2006) and Vidal et al. (2006), respectively.

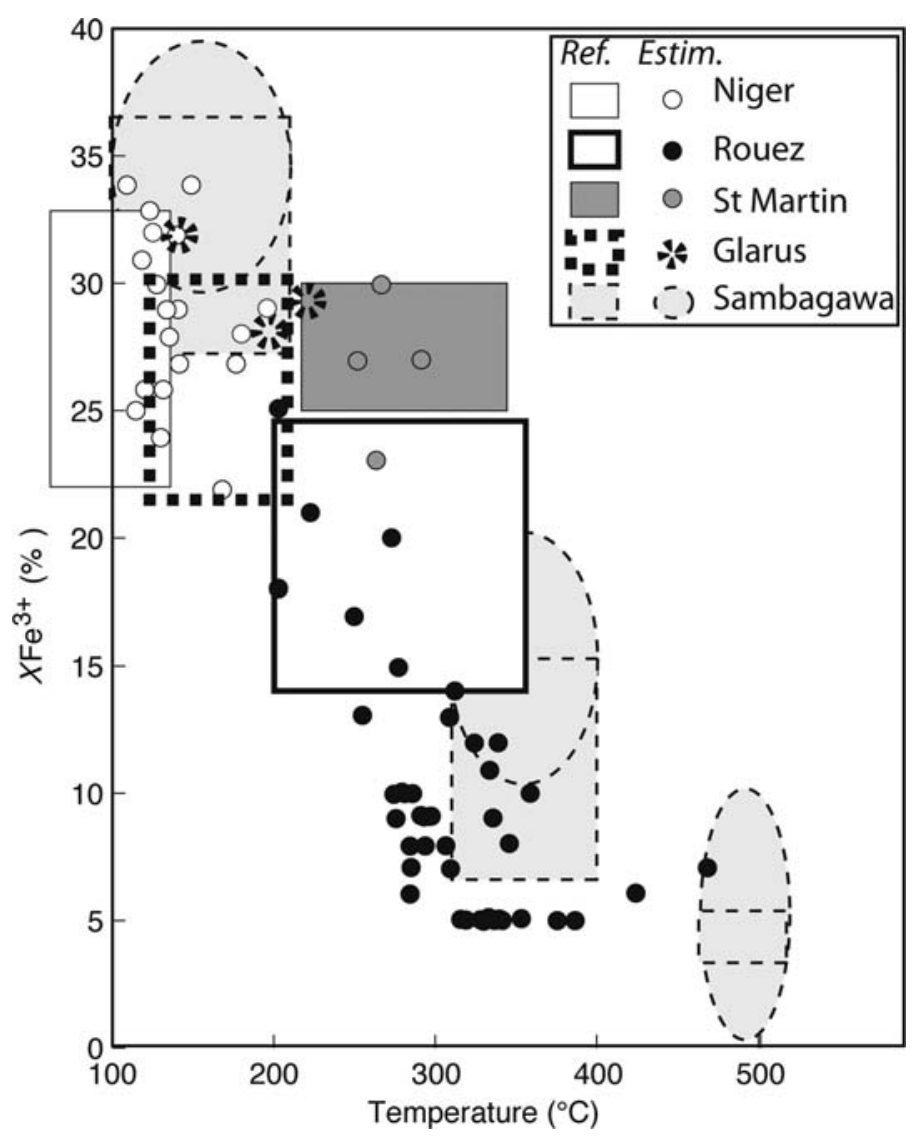

FIG. 7. Boxes: measured $X \mathrm{Fe}^{3+}$ and reference temperatures. Symbols: $T_{\text {maximum }}-X \mathrm{Fe}^{3+}$ minimum pairs calculated to obtain convergence $\left( \pm 30^{\circ} \mathrm{C}\right)$ of equilibria $1,8,9$ and 10 with the thermodynamic model of Vidal et al. (2006). 
For each series of Inoue et al. (2009), between 50 and $60 \%$ of the chlorite analyses contain $\mathrm{Si}<3$ a.p.f.u. and led to a convergence of equations $1,8,9$ and 10 within $30^{\circ} \mathrm{C}$. The calculated $T-X \mathrm{Fe}^{3+}$ pairs are plotted in Fig. 7 and compared with the range of reference temperature (TRef) estimated independently and $X \mathrm{Fe}^{3+}$ measures reported by Inoue et al. (2009). A fair agreement of the measured and calculated $T \mathrm{Fe}^{3+}$ Vidal$X \mathrm{Fe}^{3+}$ values is observed for the Niger and St-Martin analyses, and a good agreement of the TRef and $T \mathrm{Fe}^{3}$ + Vidal was observed for the Rouez samples, but the calculated values were smaller than the measured values for $X \mathrm{Fe}^{3+}$ for this samples. However, the $X \mathrm{Fe}^{3+}$ values reported in Fig. 7 are minimum values required to obtain convergence of equilibria 1 and 8-10 within $30^{\circ} \mathrm{C}$. Convergence is maintained at higher values of $X \mathrm{Fe}^{3+}$ and $T \mathrm{Fe}^{3+}$ Vidal for the Rouez samples are still located in the range of TRef when $X \mathrm{Fe}^{3+}$ is set at $>15 \%$ (lower limit of the reference values). The $T \mathrm{Fe}^{3+}$ Vidal values calculated for the Glarus chlorite analyses listed in Bourdelle et al. (2013c) are $139^{\circ}$ $\mathrm{C}, 203^{\circ} \mathrm{C}$ and $224^{\circ} \mathrm{C}$, in fair agreement with those estimated independently by Bourdelle et al. (2013c) $\left(135^{\circ} \mathrm{C}, 170^{\circ} \mathrm{C}\right.$ and $182^{\circ} \mathrm{C}$, respectively) or with the semi-empirical thermometer of Inoue et al. (2009) $\left(145^{\circ} \mathrm{C}, 196^{\circ} \mathrm{C}\right.$ and $210^{\circ} \mathrm{C}$, respectively). For the three samples studied, the $X \mathrm{Fe}^{3+}$ values measured using XANES (X-ray absorption near edge structure) spectra in the transmission mode of scanning transmission X-ray microscopy (STXM) were found to be $22.3,23.8$ and $27.9 \%$. These values compare favourably with the estimated ones $(32,27$ and $28 \%$, respectively), although the measured values suggest an increase in $X \mathrm{Fe}^{3+}$ with temperature, which is contrary the trend inferred from the thermodynamic estimates and evidenced in Figs 6 and 7. Finally, the range of $X \mathrm{Fe}^{3+}$ estimated for the different generations of chlorite in the Sambagawa sample (ellipses in Fig. 7) are slightly higher but still in fair agreement with those inferred from the XANES measurements. In conclusion, Fig. 7 shows that the values estimated on the basis of the convergence of equilibria $(1,8,9$ and 10) are consistent with the TRef and measured $X \mathrm{Fe}^{3+}$ for various samples covering a range of temperature from $100^{\circ} \mathrm{C}$ to $500^{\circ} \mathrm{C}$, pressure from $\sim 2$ to $10 \mathrm{kbar}$, and $X \mathrm{Fe}^{3+}$ values from 5 to $35 \%$. Both the measured and estimated $X \mathrm{Fe}^{3+}$ values plotted in Fig. 7 seem to confirm the systematic decrease of $X \mathrm{Fe}^{3+}$ with increasing temperature and increase with increasing pressure that was observed in Fig. 6. This trend is similar to the decrease in vacancy observed in Fig. 5.

\section{$a \mathrm{O}_{2}$-TEMPERATURE ESTIMATES AND ADDITION OF A FERRI- SUDOITE END-MEMBER}

The general trends inferred from our compilation of natural samples indicate that $X \mathrm{Fe}^{3+}$ increases with decreasing temperature and increasing pressure. Although the model of Vidal et al. (2006) involves no $\mathrm{Fe}^{3+}$-bearing end-member, the oxygen activity $\left(a \mathrm{O}_{2}\right)$ prevailing during the formation of chlorites used to compute Fig. 7 can be estimated assuming that it was buffered by the presence of pure magnetite (Mt) in equilibrium with chlorite and quartz. Following this assumption, $a \mathrm{O}_{2}$ for each sample has been calculated using equilibria $(1,8,9,10)$ and the following additional equilibria, which intersect at the same $P, T$ $\left( \pm 30^{\circ} \mathrm{C}\right),\left(X \mathrm{Fe}^{3+}\right) \mathrm{Chl}$ and $\log \left(a \mathrm{O}_{2}\right)( \pm 2)($ Fig. 8):

$$
\begin{aligned}
& 15 \mathrm{Mg}-\mathrm{Sud}+40 \mathrm{Mt}+45 \mathrm{Qtz}+60 \mathrm{H}_{2} \mathrm{O} \\
& =6 \mathrm{Clin}+24 \mathrm{Daph}+20 \mathrm{O}_{2} \\
& 6 \mathrm{Mg}-\mathrm{Sud}+10 \mathrm{Mt}+6 \mathrm{Qtz}+12 \mathrm{H}_{2} \mathrm{O} \\
& \quad=3 \mathrm{Mg}-\mathrm{Am}+6 \mathrm{Daph}+5 \mathrm{O}_{2} \\
& 15 \mathrm{Mg}-\text { Sud }+6 \mathrm{Clin}+10 \mathrm{Mt} \\
& =15 \mathrm{Qtz}+15 \mathrm{Mg}-\mathrm{Am}+6 \mathrm{Daph}+5 \mathrm{O}_{2}
\end{aligned}
$$

$6 \mathrm{Daph}+4 \mathrm{Clin}+5 \mathrm{O}_{2}$

$$
=20 \mathrm{Qtz}+10 \mathrm{Mt}+5 \mathrm{Mg}-\mathrm{Am}+20 \mathrm{H}_{2} \mathrm{O}
$$

$60 \mathrm{Mg}-\mathrm{Sud}+12 \mathrm{Clin}+70 \mathrm{Mt}+60 \mathrm{H}_{2} \mathrm{O}$

$$
=45 \mathrm{Mg}-\mathrm{Am}+42 \mathrm{Daph}+35 \mathrm{O}_{2}
$$

$$
4 \mathrm{Qtz}+2 \mathrm{Mt}+\mathrm{Fe}-\mathrm{Am}+4 \mathrm{H}_{2} \mathrm{O}
$$$$
=2 \mathrm{Daph}+\mathrm{O}_{2}
$$

$15 \mathrm{Mg}-\mathrm{Sud}+6 \mathrm{Daph}+10 \mathrm{Mt}$

$$
=15 \mathrm{Qtz}+6 \mathrm{Clin}+15 \mathrm{Fe}-\mathrm{Am}+5 \mathrm{O}_{2}
$$

$60 \mathrm{Mg}-\mathrm{Sud}+70 \mathrm{Mt}+60 \mathrm{H}_{2} \mathrm{O}$

$$
=24 \mathrm{Clin}+45 \mathrm{Fe}-\mathrm{Am}+6 \mathrm{Daph}+35 \mathrm{O}_{2}
$$

$15 \mathrm{Mg}-\mathrm{Sud}+16 \mathrm{Mt}+12 \mathrm{H}_{2} \mathrm{O}$

$$
=3 \mathrm{Qtz}+6 \mathrm{Clin}+12 \mathrm{Fe}-\mathrm{Am}+8 \mathrm{O}_{2}
$$

$6 \mathrm{Mg}-\mathrm{Sud}+4 \mathrm{Mt}$

$$
=6 \mathrm{Qtz}+3 \mathrm{Mg}-\mathrm{Am}+3 \mathrm{Fe}-\mathrm{Am}+2 \mathrm{O}_{2}
$$

$12 \mathrm{Mg}-\mathrm{Sud}+14 \mathrm{Mt}+12 \mathrm{H}_{2} \mathrm{O}$

$$
=6 \mathrm{Mg}-\mathrm{Am}+3 \mathrm{Fe}-\mathrm{Am}+6 \mathrm{Daph}+7 \mathrm{O}_{2}
$$

$5 \mathrm{Mg}-\mathrm{Am}+4 \mathrm{Mt}+8 \mathrm{Qtz}+8 \mathrm{H}_{2} \mathrm{O}$

$=4 \mathrm{Clin}+3 \mathrm{Fe}-\mathrm{Am}+2 \mathrm{O}_{2}$

$24 \mathrm{Mg}-\mathrm{Sud}+3 \mathrm{Mg}-\mathrm{Am}+28 \mathrm{Mt}+24 \mathrm{H}_{2} \mathrm{O}$

$=12 \mathrm{Clin}+21 \mathrm{Fe}-\mathrm{Am}+14 \mathrm{O}_{2}$

All calculated $\log \left(a \mathrm{O}_{2}\right)$ except those of the Saint- 

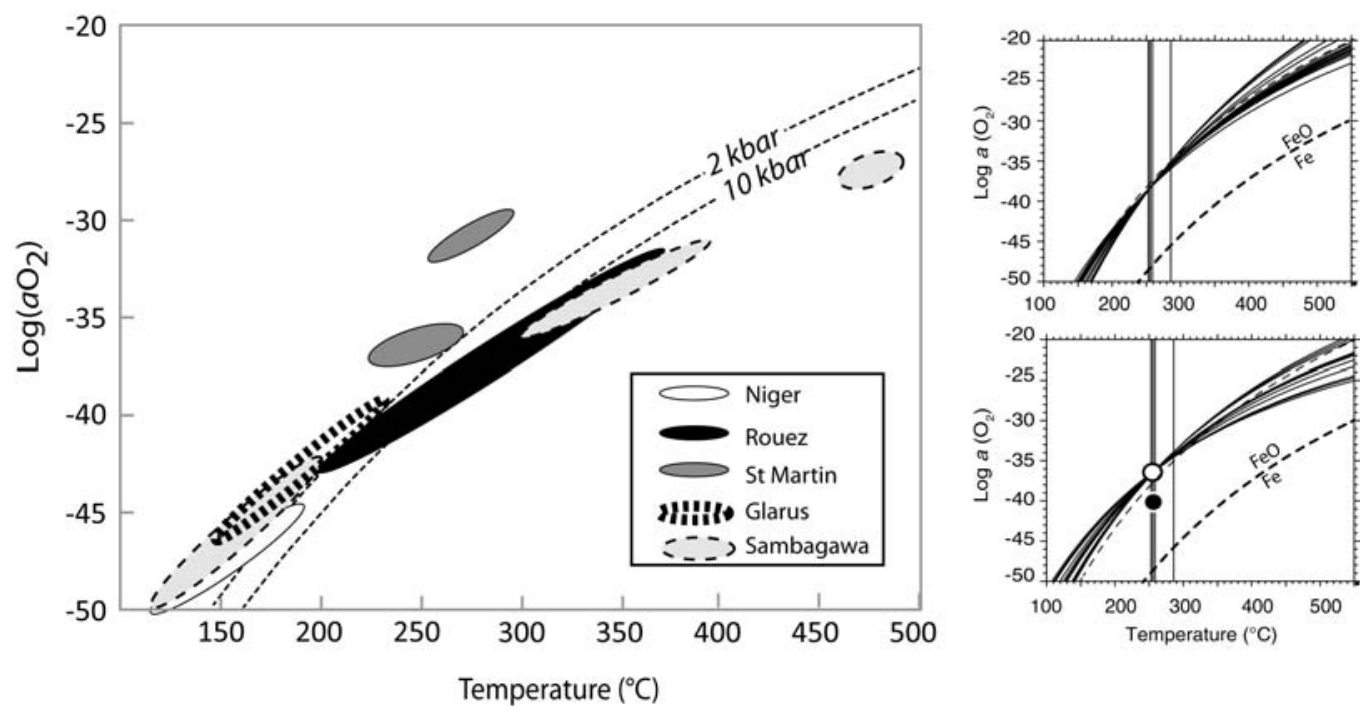

FIG. 8. Left: Ranges of $\log \left(a \mathrm{O}_{2}\right)$ conditions calculated for the samples used to compute Fig. 7 at the temperature and $X \mathrm{Fe}^{3+}$ contents estimated from the Chl-Qtz- $\mathrm{H}_{2} \mathrm{O}$ equilibrium conditions. Dashed lines: hematite-magnetite- $\mathrm{O}_{2}$ equilibrium calculated using the thermodynamic properties of Berman (1988) and unit activities of Ht and Mt. Right: Sample calculation at $2 \mathrm{kbar}$ for a Rouez sample using reactions 8-20 (upper) or 26-40 (lower). The vertical lines correspond to oxygen- and magnetite-free reactions $1,5,6$ and 7 used to compute Figs $5-7$, which converge at $+30^{\circ} \mathrm{C}$. The circles in the lower figure represent values calculated with $\left(\Delta H^{\circ} f\right)$ ferri-Sud constrained with the chlorite-magnetitequartz-water equilibria 8-20 (open circle) or estimated as $\Delta H^{\circ} f$ (Mg-sudoite) $-\Delta H^{\circ} f($ corundum $) / 2+\Delta H^{\circ} f($ hematite $) / 2$

(filled circle) (see Table 1 and text).

Martin samples follow the same trend and decrease with decreasing temperature from $\sim-27$ at $450-500^{\circ} \mathrm{C}$, $10 \mathrm{kbar}$ (high-temperature chlorites of Sambagawa) to $-50^{\circ} \mathrm{C}$ at $125^{\circ} \mathrm{C}$ and $1 \mathrm{kbar}$ (Niger samples) (Fig. 8). The $\log \left(a \mathrm{O}_{2}\right)$ values of the high- $T$ and $-P$ samples plot in the stability field of magnetite whereas those of the low- $T$ samples plot in the stability field of hematite, which is not consistent with the assumption of Chl-MtQtz- $\mathrm{H}_{2} \mathrm{O}$ equilibrium. The presence of hematite has been reported in the Saint-Martin samples only (Beaufort et al. 1992), which plot above the trend defined by the other samples (upper grey ellipse in Fig. 8). The relative position of this hematite-bearing sample is consistent with expected higher oxygen activities required for its formation. For the other low$T$ and apparently hematite-free samples, it is possible that the calculated $\log \left(a \mathrm{O}_{2}\right)$ values are too high, or that oxygen was not buffered by an equilibrium of magnetite with chlorite. In any case, Fig. 8 indicates that the systematic increase in $\left(X \mathrm{Fe}^{3+}\right) \mathrm{Chl}$ with decreasing temperature observed in Figs 6 and 7 is consistent with a lower $a \mathrm{O}_{2}$ and amount of free oxygen at low- $T$ than high- $T$ in systems where $a \mathrm{O}_{2}$ is buffered by the presence of chlorite and iron oxides. To maintain this equilibrium with lowering temperature in metamorphic rocks where oxygen is immobile, oxygen has to be consumed and one way for that is to produce chlorite that is richer in $\mathrm{Fe}^{3+}$. This is a possible interpretation for the formation of low-temperature $\mathrm{Fe}^{3+}$-rich chlorite coexisting with high-temperature $\mathrm{Fe}^{3+}$-poor chlorite in the same thin section of the Sambagwa sample (Fig. 9).

In order to discuss the $\log \left(a \mathrm{O}_{2}\right)-T-\mathrm{XFe}^{3+}$ evolution in more detail for rocks where $a \mathrm{O}_{2}$ is not buffered by the presence of magnetite, it is necessary to define an $\mathrm{Fe}^{3+}$-bearing chlorite end-member. The simultaneous increase of vacancy and $\mathrm{Fe}^{3+}$ content with decreasing temperature observed in Figs 5-7 is explained by the $3\left(\mathrm{Mg}, \mathrm{Fe}^{2+}\right)=2\left(\mathrm{Fe}^{3+}\right) \square$ di/trioctahedral substitution (see also Trincal \& Lanari, 2016, this issue). This exchange can be modelled with a ferri-sudoite endmember that materializes the relationship between $X \mathrm{Fe}^{3+}$ and vacancy. The standard-state thermodynamic properties of ferri-sudoite were constrained as follows.

(1) Because the maximum amount of $\left(\mathrm{Fe}^{3+}\right) \mathrm{Chl}$ calculated in the previous section never exceeded 1 a.p.f.u., the cation distribution of Vidal et al. (2006) 


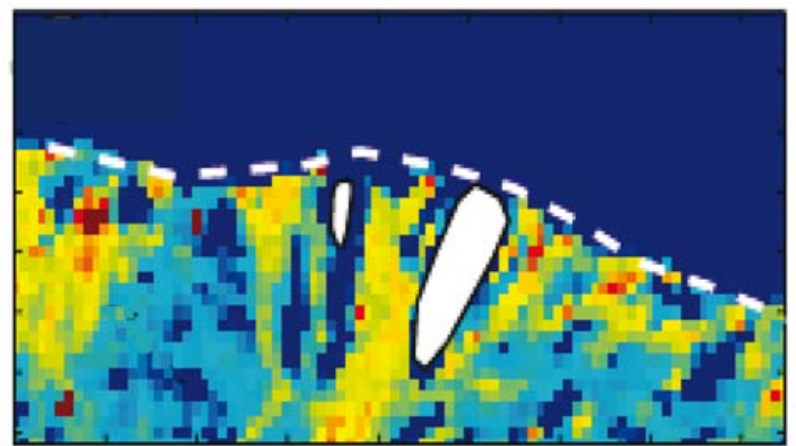

b
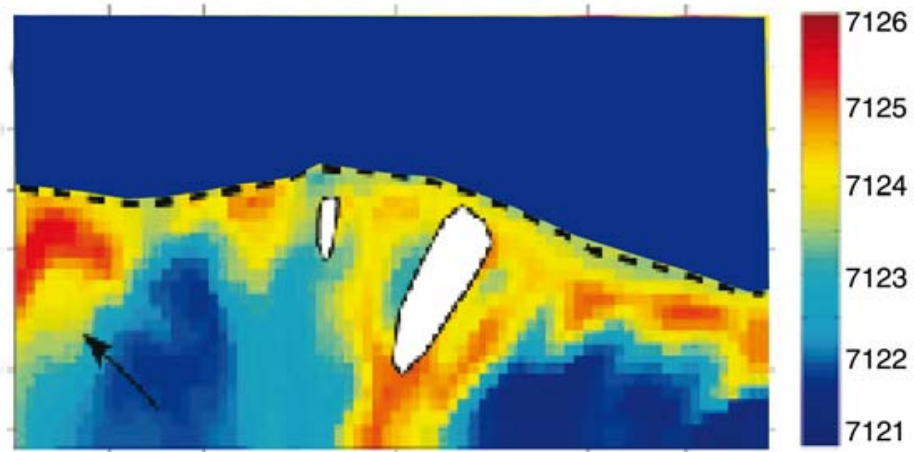

c

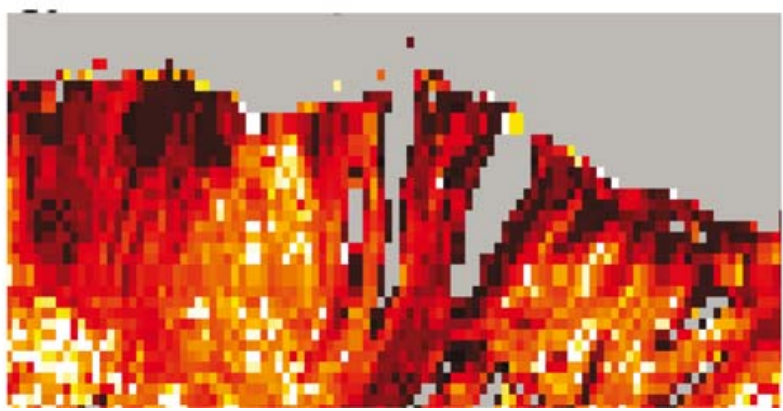

$X \mathrm{Fe}^{3+} \log \left(\mathrm{aO}_{2}\right)$

0.4

$-50$

0.3

$-42$

0.2

$-32$

0.1

$-25$

FIG. 9. Rock-sample mapping of a Sambagawa sample: (a) maps of estimated $X \mathrm{Fe}^{3+}$ (Vidal et al., 2006; Munoz et al., 2006) and $\log \left(a \mathrm{O}_{2}\right)$ (estimated assuming that it is buffered by magnetite-chlorite equilibria, see text and Fig. 8); (b) measured Fe XANES edge-position proportional to Fe redox (Munoz et al., 2006); (c) estimated temperature (Vidal et al., 2006; Munoz et al., 2006).

was kept unchanged and the $\mathrm{Fe}^{3+}-\mathrm{Al}^{3+}$ exchange was assumed to be restricted to the M4 site of chlorite. The chosen formula of ferri-Sud was thus $\left(\left[\mathrm{Si}_{2}\right]_{\mathrm{T} 1}[\mathrm{Si}\right.$, $\left.\mathrm{Al}]_{\mathrm{T} 2}\right)^{\mathrm{IV}}\left([\square]_{\mathrm{M} 1}\left[\mathrm{Mg}_{2}, \mathrm{Al}_{2}\right]_{\mathrm{M} 2-3}\left[\mathrm{Fe}^{3+}\right]_{\mathrm{M} 4}\right)^{\mathrm{VI}} \mathrm{O}_{10}(\mathrm{OH})_{8}$. The standard-state thermodynamic properties of all other chlorite end-members, the activity model and the Margules parameters were kept unchanged.
(2) The third-law entropy of ferri-sudoite $\left(S^{\circ}=\right.$ $415 \mathrm{~J} / \mathrm{mol} / \mathrm{K}$ ) was estimated according to Holland (1989) with a configurational entropy of $23.05 \mathrm{~J} / \mathrm{mol} / \mathrm{K}$ and a ferromagnetic contribution of $13.04 \mathrm{~J} / \mathrm{mol} / \mathrm{K}$, its volume $\left(V^{\circ}=20.4 \mathrm{~J} / \mathrm{b}\right)$ was estimated to be $0.1 \mathrm{~J} / \mathrm{b}$ lower than that of $\mathrm{Mg}$-sudoite $(20.51 \mathrm{~J} / \mathrm{b})$ and the $\mathrm{Cp}$ $(T)$ function was estimated according to Berman \& 
Brown (1985). The formation enthalpy $\left(\Delta H^{\circ} f=8225\right.$. $4 \pm 5 \mathrm{~kJ} / \mathrm{mol}$ ) was first estimated as the average value between that calculated according to Chermak \& Rimstidt (1989) $(-8220.4 \mathrm{~kJ} / \mathrm{mol})$ and that $(-8230.4 \mathrm{~kJ} / \mathrm{mol})$ calculted as $\Delta H^{\circ} f(\mathrm{Mg}$-sudoite $)-$ $\Delta H^{\circ} f$ (corundum) $/ 2+\Delta H^{\circ} f$ (hematite) $/ 2$ using the values of Vidal et al. (1992) for sudoite and Berman (1988) for hematite.

(3) In a first step, $\Delta H^{\circ} f$ and $S^{\circ}$ of ferri-sudoite were adjusted in order to reproduce the temperatures reported in Fig. 7 with oxygen-free reactions and assuming that magnetite is present in all samples (Chl-Qtz-Mt assemblage). $\Delta H^{\circ} f$ was allowed to vary between -8220 and $-8230 \mathrm{~kJ} / \mathrm{mol}$ and $S^{\circ}$ within $10 \mathrm{~J} /$ $\mathrm{mol} / \mathrm{K}$ of the estimated value. The addition of magnetite and ferri-sudoite to quartz and water leads to 17 additional equilibria, and the following were used to constrain $\Delta H^{\circ} f$ and $S^{\circ}$ of ferri-sudoite:

$$
\text { Clin }+\mathrm{Mg}-\mathrm{Sud}=\mathrm{Mg}-\mathrm{Am}+\mathrm{Qtz}+\mathrm{H}_{2} \mathrm{O}
$$

$$
\begin{aligned}
& 4 \text { Clin + Daph + } 10 \text { ferri-Sud } \\
& =10 \mathrm{Mg}-\mathrm{Am}+25 \mathrm{Qtz}+30 \mathrm{Mt}+20 \mathrm{H}_{2} \mathrm{O}
\end{aligned}
$$

$$
\begin{aligned}
& 7 \text { Daph }+70 \text { ferri-Sud }+30 \mathrm{Mg}-\mathrm{Am} \\
& =22 \mathrm{Clin}+75 \mathrm{Mg}-\mathrm{Sud}+35 \mathrm{Mt}+40 \mathrm{H}_{2} \mathrm{O}
\end{aligned}
$$

$$
\begin{aligned}
& 28 \text { ferri-Sud }+11 \text { Fe-Am }+\mathrm{Mg}-\mathrm{Am} \\
& =6 \mathrm{Daph}+30 \mathrm{Mg}-\mathrm{Sud}+14 \mathrm{Mt}+16 \mathrm{H}_{2} \mathrm{O}
\end{aligned}
$$

$$
\begin{gathered}
\text { Daph }+10 \text { ferri-Sud }+10 \mathrm{Mg}-\mathrm{Am}+10 \mathrm{Qtz} \\
=6 \mathrm{Clin}+15 \mathrm{Mg}-\mathrm{Sud}+5 \mathrm{Mt}+16 \mathrm{H}_{2} \mathrm{O}
\end{gathered}
$$

The ferri-Sud properties derived with the assumption of Chl-Qtz-Mt equilibrium are listed in Table 1 (referenced a). With these values, the oxygen activity at the $P, T$ and $\left(X \mathrm{Fe}^{3+}\right) \mathrm{Chl}$ of all equilibria used to compute Fig. 7 can be calculated with the following oxygen-bearing and magnetite-free equilibria, which converge with equilibria $1,8,9$ and 10 at the same $P, T$ and $a \mathrm{O}_{2}$ conditions:

$$
\begin{gathered}
16 \mathrm{Qtz}+7 \mathrm{Mg}-\mathrm{Am}+4 \mathrm{Daph}+6 \mathrm{Mg}-\mathrm{Sud} \\
+5 \mathrm{O}_{2}+12 \mathrm{H}_{2} \mathrm{O}=20 \text { ferri-Sud }
\end{gathered}
$$

$\mathrm{Fe}-\mathrm{Am}+2 \mathrm{Mg}-\mathrm{Am}+6 \mathrm{Qtz}+4 \mathrm{H}_{2} \mathrm{O}+\mathrm{O}_{2}$ $=4$ ferri-Sud

$\mathrm{Mg}-\mathrm{Am}+4 \mathrm{Daph}+6 \mathrm{Mg}-\mathrm{Sud}+2 \mathrm{O}_{2}$ $=3$ Fe-Am +8 ferri-Sud +2 Qtz
$5 \mathrm{Mg}-\mathrm{Am}+12 \mathrm{Daph}+18 \mathrm{Mg}-\mathrm{Sud}+7 \mathrm{O}_{2}+4 \mathrm{H}_{2} \mathrm{O}$ $=8 \mathrm{Fe}-\mathrm{Am}+28$ ferri-Sud

$8 \mathrm{Daph}+12 \mathrm{Mg}-\mathrm{Sud}+3 \mathrm{O}_{2}=7 \mathrm{Fe}-\mathrm{Am}$

+12 ferri-Sud $+10 \mathrm{Qtz}+4 \mathrm{H}_{2} \mathrm{O}$

$6 \mathrm{Clin}+4 \mathrm{Daph}+15 \mathrm{Mg}-\mathrm{Sud}+5 \mathrm{O}_{2}$

$=5 \mathrm{Mg}-\mathrm{Am}+20$ ferri-Sud $+5 \mathrm{Qtz}$

4 Clin +20 ferri-Sud $=30$ Qtz

$$
+15 \mathrm{Mg}-\mathrm{Am}+4 \mathrm{Daph}+5 \mathrm{O}_{2}+20 \mathrm{H}_{2} \mathrm{O}
$$

$90 \mathrm{Mg}-\mathrm{Sud}+28 \mathrm{Daph}+32 \mathrm{Clin}+20 \mathrm{H}_{2} \mathrm{O}+35 \mathrm{O}_{2}$

$=140$ ferri-Sud +15 Mg-Am

$15 \mathrm{Qtz}+14 \mathrm{Clin}+16 \mathrm{Daph}+45 \mathrm{Mg}-\mathrm{Sud}$

$+20 \mathrm{O}_{2}+20 \mathrm{H}_{2} \mathrm{O}=80$ ferri-Sud

$2 \mathrm{Clin}+\mathrm{FeAm}+3 \mathrm{Mg}-\mathrm{Sud}+\mathrm{O}_{2}$

$=2 \mathrm{Mg}-\mathrm{Am}+4$ ferri-Sud $+\mathrm{Qtz}$

$12 \mathrm{Clin}+7 \mathrm{Fe}-\mathrm{Am}+18 \mathrm{Mg}-\mathrm{Sud}+7 \mathrm{O}_{2}+4 \mathrm{H}_{2} \mathrm{O}$ $=10 \mathrm{Mg}-\mathrm{Am}+28$ ferri-Sud

$5 \mathrm{Qtz}+2 \mathrm{Clin}+2 \mathrm{Fe}-\mathrm{Am}+3 \mathrm{Mg}-\mathrm{Sud}$

$+2 \mathrm{O}_{2}+4 \mathrm{H}_{2} \mathrm{O}=8$ ferri-Sud

$2 \mathrm{Clin}+8 \mathrm{Daph}+15 \mathrm{Mg}-\mathrm{Sud}+5 \mathrm{O}_{2}$

$=5 \mathrm{Fe}-\mathrm{Am}+20$ ferri-Sud $+5 \mathrm{Qtz}$

$30 \mathrm{Qtz}+8 \mathrm{Clin}+15 \mathrm{Fe}-\mathrm{Am}+5 \mathrm{O}_{2}+20 \mathrm{H}_{2} \mathrm{O}$

$=8$ Daph +20 ferri-Sud

$4 \mathrm{Clin}+8 \mathrm{Daph}+18 \mathrm{Mg}-\mathrm{Sud}+7 \mathrm{O}_{2}+4 \mathrm{H}_{2} \mathrm{O}$

$=3 \mathrm{Fe}-\mathrm{Am}+28$ ferri-Sud

Because the ferri-sudoite standard-state properties were constrained by the chlorite-quartz-magnetite$\mathrm{O}_{2}-\mathrm{H}_{2} \mathrm{O}$ equilibrium, the $\log \left(a \mathrm{O}_{2}\right)$ calculated with the equilibria above follow naturally the trend shown in Fig. 8, and the $\log \left(a \mathrm{O}_{2}\right)$ values calculated with reactions 28-42 of low-temperature samples plot in the hematite stability field. This suggests that the $\Delta G^{\circ P T}$ values of ferri-sudoite derived above with the assumption that $a \mathrm{O}_{2}$ is buffered by the presence of magnetite are possibly too high. A reduction of $\Delta H^{\circ} f$ (ferri-sudoite) to $8230.4 \mathrm{~kJ} / \mathrm{mol}\left(=\Delta H^{\circ} f\right.$ (Mg-sudoite) $-\Delta H^{\circ} f$ (corundum) $/ 2+\Delta H^{\circ} f($ hematite $) / 2$, see Table 1$)$ leads to $\log \left(a \mathrm{O}_{2}\right)$ reduced by $4.5 \mathrm{Log}$ units (see Fig. 8) 
and most calculated values except those of the hematite-bearing St. Martin samples plot in the magnetite stability field.

A more detailed study is required to refine the ferrisudoite thermodynamic data. However, the results obtained using the preliminary values listed in Table 1 show that this end-member can be used to reproduce consistently the $T-X \mathrm{Fe}^{3+}$ and $T-\square$ trends obtained from classical Chl-Qtz- $\mathrm{H}_{2} \mathrm{O}$ calculations (Figs 5-7). The increase in $X \mathrm{Fe}^{3+}$ with reducing temperature is consistent with the expected reduction in $a \mathrm{O}_{2}$ and the amount of free oxygen that is consumed to produce $\mathrm{Fe}^{3+}$-bearing chlorite. Ferric iron is therefore a major component that has to be taken into account when dealing with lowtemperature samples. Empirical or semi-empirical chlorite thermometers which assume that all $\mathrm{Fe}$ is in the ferrous state may include one of the $X \mathrm{Fe}^{3+}-T$ and $a \mathrm{O}_{2}-T$ trends illustrated in Figs 7 and 8 , but they cannot account for the different $X \mathrm{Fe}^{3+}-T$ trends that are expected in the contexts of different $a \mathrm{O}_{2}$ conditions.

FUTURE CHALLENGES: LOOKING AT LOW-GRADE ROCKS SUCH AS METAMORPHIC ROCKS AND THE DYNAMICS OF CHLORITE CRYSTALLIZATION AT THE MICROMETRIC TO NANOMETRIC SCALE

T-P-XFe ${ }^{3+}$ mapping at the thin-section scale: evidence of chlorite composition reequilibration in metamorphic and low-grade samples

Although natural samples offer valuable constraints on thermodynamic models, there are two main difficulties in using them to evaluate the reliability of existing chlorite models for thermometric purposes:

(1) In the case of low-grade samples, reference pressures and temperatures are generally known within a reasonable absolute uncertainty, but the size of chlorite grains is often small and good microprobe analyses are sometimes difficult to obtain. Moreover, the kinetics of reaction are so sluggish that inherited chlorite grains might remain unaffected by later variations in temperature, which makes the temperature-composition relationships difficult to constrain. Lastly, extrapolation at $\mathrm{H} T$ and $\mathrm{H} P$ of empirical or semi-empirical models constrained by LT samples only may be erroneous; in particular, the effect of pressure or eventual systematic variations of $X \mathrm{Fe}^{3+}$ cannot be appraised.
(2) In the case of metamorphic samples, microprobe analyses are easier to obtain from large chlorite grains, but chlorites of contrasted composition that crystallized at different temperatures and times of the metamorphic history are often observed to coexist metastably in different microstructural sites of the same thin section. In such cases, the definition of a single pair of reference temperature and pressure is inappropriate and cannot be restricted to the peaktemperature conditions.

In order to overcome these difficulties and to better visualize the link between mineral composition, deformation and $P-T$ conditions at the thin-section scale, de Andrade et al. (2006, 2011), Vidal et al. (2006) and Lanari et al. (2013) developed an approach which combines elementary maps of composition with either a thermodynamic or a semi-empirical estimate of chlorite crystallization temperature. Maps of raw microprobe analyses were standardized using goodquality point analyses of minerals present in the mapped area. The maps of standardized analyses were transformed into maps of structural formulae where each pixel analysed is converted into individual mineral structural formulae. Depending on the thermometric approach, it was then possible to compute maps of temperature or $T-\mathrm{XFe}^{3+}$ conditions assuming that each chlorite pixel was in equilibrium with quartz and water. The results reported by Vidal et al. (2006), Yamato et al. (2007), Ganne et al. (2012), Lanari et al. (2013, 2014) and Scheffer et al. (2015) showed a close link between deformation and mineral reaction at the microscopic scale, and maps of chlorite temperature could be used as a basis for interpreting the microstructures observed in thin sections of low- to middlegrade metapelites. In all these studies, the metastable persistence of different generations of chlorite crystallizing at different temperatures during the exhumation of metamorphic samples could be used to constrain the $T$-deformation history. Moreover, the map of $\left(X \mathrm{Fe}^{3+}\right)$ Chl calculated by Vidal et al. (2006) was in good qualitative agreement with the in situ mapping of this ratio using the X-ray absorption near-edge structure (XANES) techniques (Fig. 9) (see also Munoz et al., 2006). The calculated temperature and $X \mathrm{Fe}^{3+}$ maps obtained on a single sample showed the same trend of reducing $\left(X \mathrm{Fe}^{3+}\right) \mathrm{Chl}$ with increasing temperature as observed in Figs 6 and 7.

Bourdelle et al. (2013c) applied a similar approach for low-temperature samples with chlorite of small grain size using transmission electron microscopyenergy dispersive X-ray (TEM-EDX) spectroscopic analyses of focused-ion beam (FIB) foils instead of 


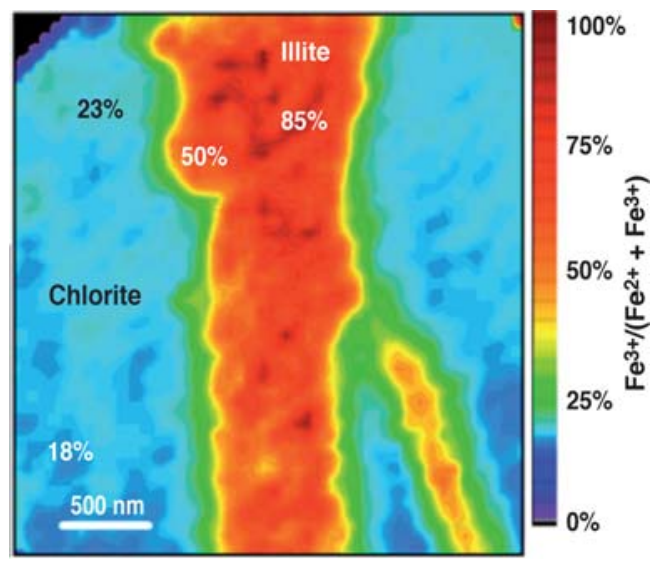

FIG. 10. Quantitative Fe redox nanomapping on a FIB foil of Glarus sample $\left(T<300^{\circ} \mathrm{C}\right.$; Switzerland), calculated from the 708.7-710.25 eV images ratio (STXM-XANES)

(from Bourdelle et al., 2013c).

microprobe analyses of thin sections (Fig. 10). Those authors were able to observe heterogeneities in $X \mathrm{Fe}^{3+}$ at the nm scale using STXM-XANES measurements. This last study was particularly interesting as it showed that approaches similar to those used for studying metamorphic rocks could be applied to low-grade and diagenetic samples.

\section{Looking at diagenetic rocks like metamorphic} rocks

The use of equilibrium thermodynamics to study low-grade rocks has been often criticized because sluggish kinetics might preclude achievement of global equilibrium at low temperature and is responsible for the crystallization of metastable phases with a lower energy of nucleation than stable ones. Essene \& Peacor (1995) claimed that the coexistence of chemically inhomogeneous phases at a very fine scale in lowgrade rocks is indicative of disequilibrium and that mineral reaction is better described by a kinetic rather than thermodynamic approach. However, the coexistence of chemically inhomogeneous phases is also a common observation in metamorphic rocks, where zoned grains and the coexistence, for example, of chlorite grains of different compositions indicate that thermodynamic equilibrium is approached only locally and at a given time in the metamorphic history. In fact, the main difference between diagenetic and highertemperature rocks is the size of the domains in local equilibrium. The more sluggish kinetics of reaction and diffusivity at low temperature lead to small grains and domains in equilibrium, but these domains can be identified when using appropriate analytical tools and procedures developed recently (Bourdelle et al., $2013 b, c)$.

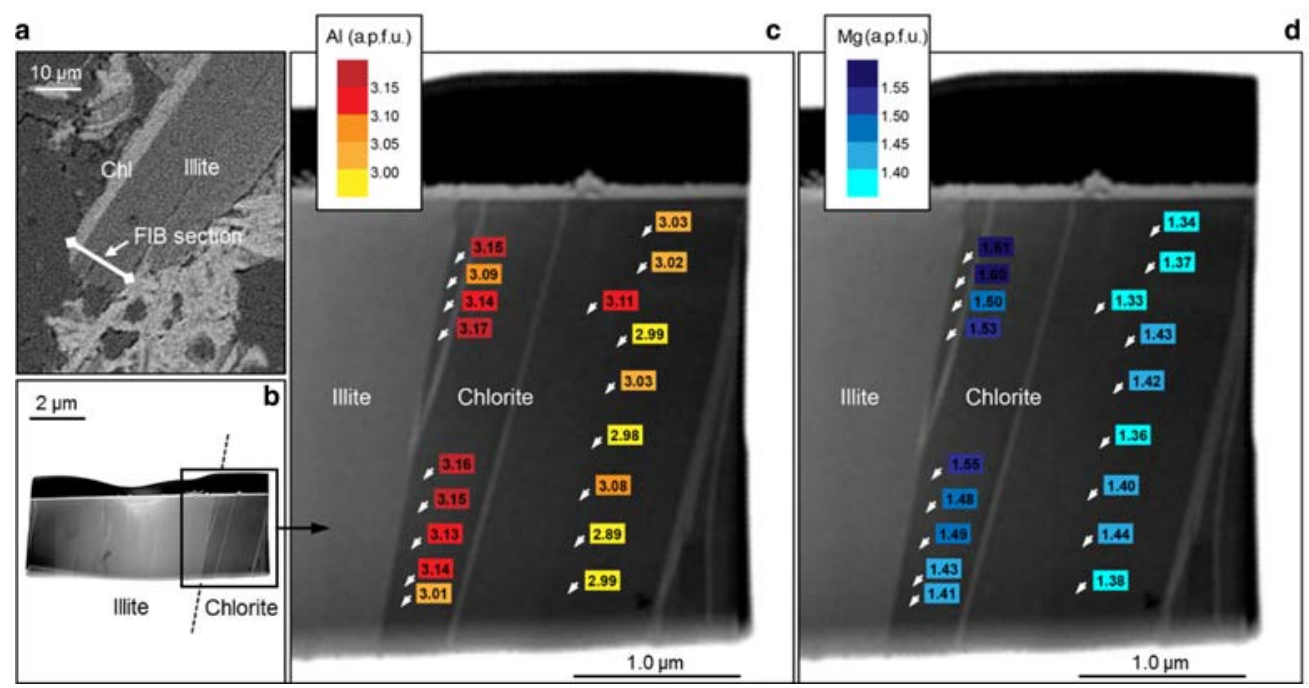

FIG. 11. Analysis of an illite-chlorite assemblage (Gulf Coast sample, Alamo 1 well, $5825 \mathrm{~m}$ ). (a) SEM image of the petrographic thin section showing the emplacement of the FIB foil to be cut across the illite-chlorite interface. (b) Bright-field TEM image of the FIB foil extracted from the section, with the platinum strap on top of it. (c,d) Enlargement of part b showing the $\mathrm{Al}$ and $\mathrm{Mg}$ contents of chlorite (a.p.f.u.) and their variation between crystal core and crystal rim. 


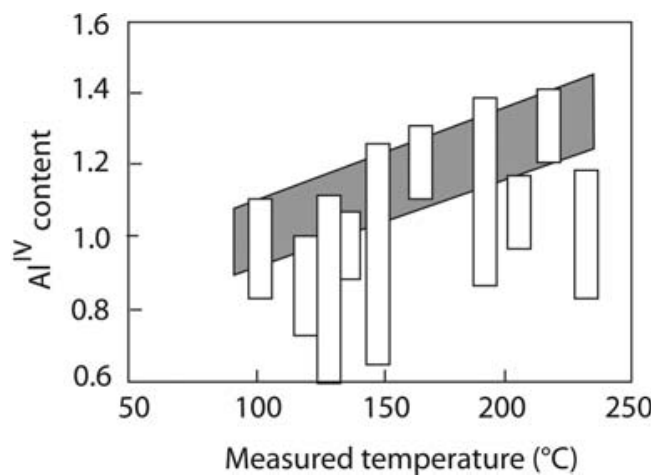

FIG. 12. Range of crystal-rim $\mathrm{Al}^{\mathrm{IV}}$ content (white boxes) of Gulf Coast chlorites vs. measured temperatures. The grey area underlines the range of maximum $\mathrm{Al}^{\mathrm{IV}}$ content, which is assumed to represent the closest approach to equilibrium composition (after Bourdelle et al., 2013b).

Figure 10 shows that it is possible to demonstrate heterogeneities in $X \mathrm{Fe}^{3+}$ contents at the nanometer scale. Consistent variations of other major elements are also observed with TEM technics on FIB foils. An example is shown in Fig. 11, which depicts the variations of $\mathrm{Al}$ and $\mathrm{Mg}$ contents in a chlorite grain from the Gulf Coast (Bourdelle et al., 2013b). In this case, the FIB foil was cut parallel to the interface between illite and chlorite, and a nm-scale investigation of composition was conducted by TEM-EDX analysis. The rim and core compositions showed a zoning of chlorite with $\mathrm{Mg}$ - and Al-richer rims than core compositions. This variation in composition on a scale of $<1 \mu \mathrm{m}$ was related to various crystallization stages during burial. Chlorite sampled at different depths and various locations of the Gulf Coast area showed that zoned compositions similar to that observed in Fig. 11 are frequent (Bourdelle et al., 2013b). The $\mathrm{Al}^{\mathrm{IV}}$ in chlorite rims display a $T$ dependence that is consistent with the $\mathrm{km}$-scale and regional evolution of temperature, i.e. with the diagenetic history of Gulf Coast (burial, $P-T$ conditions, detrital/authigenic compositions, etc...) (Fig. 12). This study suggests again that approaches used for metamorphic rocks can be applied to lowgrade rocks when using adapted analytical tools able to identify sub- $\mu \mathrm{m}$ variations of composition.

\section{CONCLUSION}

The variability of chlorite composition reflects the variability of its conditions of formation. Numerous efforts have been made over the last 30 years to translate the composition of chlorite in terms of its temperature of formation. The first empirical equations based on the $\mathrm{Al}^{\mathrm{IV}}$ or vacancy contents are restricted to bulk-rock compositions and pressure conditions at which they were calibrated. Thermodynamic approaches and semi-empirical equations based on the ratio of end-member activities do not present this limit. Among the different thermodynamic models of chlorite published so far, Vidal et al. (2006) proposed a model that can be used to estimate $T$ and $\left(X \mathrm{Fe}^{3+}\right) \mathrm{Chl}$ simultaneously. The estimated $\left(X \mathrm{Fe}^{3+}\right) \mathrm{Chl}$ values are consistent with those measured by Mössbauer or XANES spectroscopy and for the same $\left(X \mathrm{Fe}^{3+}\right) \mathrm{Chl}$, the temperatures estimated using the method of Vidal et al. (2006) are similar to those obtained with the semi-empirical equations of Inoue et al. (2009) and Lanari et al. (2014). Different $T-X \mathrm{Fe}^{3+}$ trends are observed for different pressure gradients and oxygen -buffering assemblages (Lanari et al., 2014), but overall the systematic increase in $X \mathrm{Fe}^{3+}$ with a reduction in temperature is compatible with the decrease in $a \mathrm{O}_{2}$ in a closed system. The increase in $X \mathrm{Fe}^{3+}$ and chlorite vacancy with decreasing temperature is interpreted as reflecting the incorporation of the $\mathrm{Fe}^{3+}$-sudoite component, which can be used to estimate $T-a \mathrm{O}_{2}-\mathrm{XFe}^{3+}$ values with a Chl-Qtz- $\mathrm{H}_{2} \mathrm{O}$ multi-equilibrium approach.

Similar temperatures are calculated for low-temperature chlorites $\left(T<300^{\circ} \mathrm{C}\right.$ and measured $X \mathrm{Fe}^{3+}$ up to $30 \%$ ) with all approaches assuming that iron in chlorite is either completely ferrous or with estimated values of $X \mathrm{Fe}^{3+}$. This indicates that the equations of semi-empirical thermometers, assuming that all iron in chlorite is ferrous, include some inherent $\mathrm{Fe}^{2+} / \mathrm{Fe}^{3+}$ vs. temperature correction. However, very different temperatures can be obtained for higher-temperature samples $\left(>300^{\circ} \mathrm{C}\right)$ with approaches involving ferric iron or assuming that all of the iron is ferrous. This suggests that the $\mathrm{Fe}^{2+} / \mathrm{Fe}^{3+}$ vs. temperature correction might be restricted to particular $a \mathrm{O}_{2}$ conditions and pressure gradients. More work is necessary to better understand this point and to improve the thermodynamic models and semi-empirical thermometers. This requires high-quality and well constrained natural data. To this end, mapping techniques that highlight the link between the variations in temperature and pressure and small-scale chlorite composition, including $X \mathrm{Fe}^{3+}$ variations, offer much promise. When combining the results of the present study with those of other studies published recently, it appears that thermodynamic approaches and mapping techniques developed for metamorphic rocks could be used to study low-grade 
rocks where kinetics are much more sluggish. This requires use of appropriate analytical tools and techniques with a spatial resolution of just a few hundred nanometres, which are now becoming available.

\section{ACKNOWLEDGMENTS}

Constructive reviews by S. Hillier, F. Nieto and an anonymous reviewer are gratefully acknowledged.

\section{REFERENCES}

Beaufort D., Patrier P., Meunier A. \& Ottaviani M.M. (1992) Chemical variations in assemblages including epidote and/or chlorite in the fossil hydrothermal system of Saint Martin (Lesser Antilles). Journal of Volcanology and Geothermal Research, 51, 95-114.

Berman R. (1988) Internally-consistent thermodynamic data for minerals in the system $\mathrm{Na}_{2} \mathrm{O}-\mathrm{K}_{2} \mathrm{O}-\mathrm{CaO}$ $\mathrm{MgO}-\mathrm{FeO}-\mathrm{Fe}_{2} \mathrm{O}_{3}-\mathrm{Al}_{2} \mathrm{O}_{3}-\mathrm{SiO}_{2}-\mathrm{TiO}_{2}-\mathrm{H}_{2} \mathrm{O}-\mathrm{CO}_{2}$. Journal of Petrology, 29, 445-522.

Berman R. \& Brown T. (1985) Heat capacity of minerals in the system $\mathrm{Na}_{2} \mathrm{O}-\mathrm{K}_{2} \mathrm{O}-\mathrm{CaO}-\mathrm{MgO}-\mathrm{FeO}-\mathrm{Fe}_{2} \mathrm{O}_{3}-$ $\mathrm{Al}_{2} \mathrm{O}_{3}-\mathrm{SiO}_{2}-\mathrm{TiO}_{2}-\mathrm{H}_{2} \mathrm{O}-\mathrm{CO}_{2}$ : representation, estimation, and high temperature extrapolation. Contributions to Mineralogy and Petrology, 89, 168-183.

Bourdelle F. \& Cathelineau M. (2015) Low-temperature chlorite geothermometry: a graphical representation based on a T-R2+-Si diagram. European Journal of Mineralogy, 27, 617-626.

Bourdelle F., Parra T., Chopin C. \& Beyssac O. (2013a) A new chlorite geothermometer for diagenetic to lowgrade metamorphic conditions. Contributions to Mineralogy and Petrology, 165, 723-735.

Bourdelle F., Parra T., Beyssac O., Chopin C. \& Vidal O. (2013b) Clay minerals thermometry: a comparative study based on high-resolution chemical analyses of illite and chlorite in sandstones from the Gulf Coast (Texas, USA). American Mineralogist, 98, 914-926.

Bourdelle F., Benzerara K., Beyssac O., Cosmidis J., Neuville D.R., Brown G.E. \& Paineau E. (2013c) Quantification of the ferric/ ferrous iron ratio in silicates by scanning transmission X-ray microscopy at the Fe L2,3 edges. Contribution to Mineralogy and Petrology, 166, 423-434.

Cathelineau M. (1988) Cation site occupancy in chlorites and illites as function of temperature. Clay Minerals, 23, 471-485.

Cathelineau M. \& Nieva D. (1985) A chlorite solid solution geothermometer the Los Azufres (Mexico) geothermal system. Contributions to Mineralogy and Petrology, 91, 235-244.

Chermak J.A. \& Rimstidt J.D. (1989) Estimating the thermodynamic properties $\left(\Delta \mathrm{G}^{\circ} \mathrm{f}\right.$ and $\left.\Delta \mathrm{H}^{\circ} \mathrm{f}\right)$ of silicate minerals at $298 \mathrm{~K}$ from the sum of polyhedral contributions. American Mineralogist, 74, 1023-1031.

Coggon R. \& Holland T.J.B. (2002) Mixing properties of phengitic micas and revised garnent-phengite thermobarometers. Journal of Metamorphic Geology, 20, 683-696.

Curtis C.D., Hughes C.R., Whiteman J.A. \& Whittle C.K. (1985) Compositional variation within some sedimentary chlorites and some comments on their origin. Mineralogical Magazine, 49, 375-386.

de Andrade V., Vidal O., Lewin E., O’Brien P. \& Agard P. (2006) Quantification of electron microprobe compositional maps of rock thin sections: an optimized method and examples. Journal of Metamorphic Geology, 24, 655-668.

de Andrade V., Susini J., Salomé M., Beraldin O., Rigault C., Heymes T., Lewin E. \& Vidal O. (2011) Submicrometer hyperspectral X-ray imaging of heterogeneous rocks and geomaterials: applications at the Fe k-edge. Analytical Chemistry, 83, 4220-4227.

de Caritat P., Hutcheon I. \& Walshe J. (1993) Chlorite geothermometry: a review. Clays and Clay Minerals, 41, 219-239.

Essene E.J. (2009) Thermobarometry gone astray. Pp. 101-129 in: Physics and Chemistry of Earth's Interior (A.K. Gupta \& S. Dasgupta, editors). Platinum Jubilee, Indian National Science Academy, SpringerVerlag, Berlin.

Essene E.J. \& Peacor D.R. (1995) Clay mineral thermometry - a critical perspective. Clays and Clay Minerals, 43, 540-553.

Ganne J., de Andrade V., Weinberg R.F., Vidal O., Dubacq B., Kagambega N., Naba S., Baratoux L., Jessell M. \& Allibon J. (2012) Modern-style plate subduction preserved in the Palaeoproterozoic West African craton. Nature Geoscience, 5, 60-65.

Grosch E.G., Vidal O., Abu-Alam T. \& McLoughlin N. (2012) PT constraints on the metamorphic evolution of the Paleoarchean Kromberg type-section, Barberton Greenstone Belt, South-Africa. Journal of Petrology, 53, 513-545.

Grosch E., McLoughlin N., Lanari P., Erambert M. \& Vidal O. (2014) Microscale mapping of alteration conditions and potential biosignatures in basalticultramafic rocks on early Earth and beyond. Astrobiology, 14, 216-228.

Hillier S. \& Velde B. (1991) Octahedral occupancy and chemical composition of diagenetic (low-temperature) chlorites. Clay Minerals, 26, 149-168.

Holland T.J.B. (1989) Dependance of entropy on volume for silicates and oxide minerals: A review and a predictive model. American Mineralogist, 74, 5-13.

Holland T. \& Powell R. (1998) An internally consistent thermodynamic data set for phases of petrological interest. Journal of Metamorphic Geology, 16, 309-343.

Holland T., Baker J. \& Powell R. (1998) Mixing properties and activity composition and relationships of chlorites 
in the system $\mathrm{MgO}-\mathrm{FeO}-\mathrm{Al}_{2} \mathrm{O}_{3}-\mathrm{SiO}_{2}-\mathrm{H}_{2} \mathrm{O}$. European Journal of Mineralogy, 10, 395-406.

Inoue A., Meunier A., Patrier-Mas P., Kigault C., Beaufort D. \& Vieillard P. (2009) Application of chemical geothermometry to low-temperature trioctahedral chlorites. Clays and Clay Minerals, 57, 371-382.

Jowett E. (1991) Fitting iron and magnesium into the hydrothermal chlorite geothermometer. Program Abstract, 16, A62.

Kranidiotis P. \& MacLean W. (1987) Systematics of chlorite alteration at the Phelps Dodge massive sulfide deposit, Matagami, Quebec. Economic Geology, 82, 1898-1911.

Laird J. (1988) Chlorites: Metamorphic petrology. Pp. 405-453 in: Hydrous Phyllosilicates Exclusive of Micas (S.W. Bailey, editor). Reviews in Mineralogy, 19, Mineralogical Society of America, Washington, DC.

Lanari P., Guillot S., Schwartz S., Vidal O., Tricart P., Riel N. \& Beyssac O. (2012) Diachronous evolution of the alpine continental subduction wedge: evidence from $\mathrm{P}-\mathrm{T}$ estimates in the Briançonnais Zone houillère (France-Western Alps). Journal of Geodynamics, 56, $39-54$.

Lanari P., Rolland Y., Schwartz S., Vidal O., Guillot S., Tricart P. \& Dumont T. (2013) P-T-t estimation of synkinematic strain in low-grade quartz-feldspar-bearing rocks using thermodynamic modeling and ${ }^{40} \mathrm{Ar} /{ }^{39} \mathrm{Ar}$ dating techniques: example of the Plan de Phasy shear zone unit (Briançonnais Zone, Western Alps). Terra Nova, 26, 130-138.

Lanari P., Wagner T. \& Vidal O. (2014) A thermodynamic model for di-trioctahedral chlorite from experimental and natural data in the system $\mathrm{MgO}-\mathrm{FeO}-\mathrm{Al}_{2} \mathrm{O}_{3}-$ $\mathrm{SiO}_{2}-\mathrm{H}_{2} \mathrm{O}$ : applications to $\mathrm{P}-\mathrm{T}$ sections and geothermometry. Contributions to Mineralogy and Petrology, 167, 1-19.

Munoz M., De Andrade V., Vidal O., Lewin E., Pascarelli S. \& Susini J. (2006) Redox and speciation micromapping using dispersive X-ray absorption spectroscopy: application to iron in chlorite mineral of a metamorphic rock thin section. Geochemistry, Geophysics, Geosystems, 7, Q11020.

Munoz M., Vidal O., Marcaillou C., Pascarelli O., Mathon O. \& Farges F. (2013) Iron oxidation state in phyllosilicate single crystals using $\mathrm{Fe}-\mathrm{K}$ pre-edge and XANES spectroscopy: effects of the linear polarization of the synchrotron X-ray beam. American Mineralogy, 98, 1187-1197.

Parra T., Vidal O. \& Theye T. (2005) Experimental data on the Tschermak substitution in Fe-chlorite. American Mineralogist, 90, 359-370.

Powell R. \& Holland T. (1999) Relating formulations of the thermodynamics of mineral solid solutions; activity modeling of pyroxenes, amphiboles, and micas. American Mineralogist, 84, 1-14.
Scheffer C., Vanderhaeghe O., Lanari P., Tarantola A., Ponthus L., Photiades A. \& France L. (2015) Syn to post-orogenic exhumation of high-grade nappes: structure and thermobarometry of the western AtticCycladic metamorphic complex (Lavrion, Greece). Journal of Geodynamics, 51, doi:10.1016/j. jog.2015.08.005.

Trincal V. \& Lanari P. (2016) Al-free di-trioctahedral substitution in chlorite and a ferri-sudoite end-member. Clay Minerals, 51, 675-689.

Trincal V., Lanari P., Buatier M., Lacroix B., Charpentier D., Labaume P. \& Munoz M. (2015) Temperature micro-mapping in oscillatory zoned chlorite: Application to the study of a green-schist facies fault zone near Gavarnie (Pyrenees, Spain). American Mineralogist, 100, 2468-2483.

Vidal O., Goffé B. \& Theye T. (1992) Experimental study of the stability of sudoite and magnesiocarpholite and calculation of a new petrogenetic grid for the system $\mathrm{FeO}-\mathrm{MgO}-\mathrm{Al}_{2} \mathrm{O}_{3}-\mathrm{SiO}_{2}-\mathrm{H}_{2} \mathrm{O}$. Journal of Metamorphic Geology, 10, 603-614.

Vidal O., Parra T. \& Trotet F. (2001) A thermodynamic model for $\mathrm{Fe}-\mathrm{Mg}$ aluminous chlorite using data from phase equilibrium experiments and natural pelitic assemblages in the 100 to $600 \mathrm{C}, 1$ to 25 kbar range. American Journal of Science, 301, 557-592.

Vidal O., Parra T. \& Vieillard P. (2005) Thermodynamic properties of the Tschermak solid solution in Fe-chlorite: application to natural examples and possible role of oxidation. American Mineralogist, 90, 347-358.

Vidal O., de Andrade V., Lewin E., Muñoz M., Parra T. \& Pascarelli S. (2006) P-T-deformation- $\mathrm{Fe}^{3+} / \mathrm{Fe}^{2+}$ mapping at the thin section scale and comparison with XANES mapping: application to a garnet-bearing metapelite from the Sambagawa metamorphic belt (Japan). Journal of Metamorphic Geology, 24, 669-683.

Walshe J.L. (1986) A six-component chlorite solid solution model and the conditions of chlorite formation in hydrothermal and geothermal systems. Economic Geology, 81, 681-703.

Wiewióra A. \& Weiss Z. (1990) Crystallochemical classifications of phyllosilicates based on the unified system of projection of chemical composition: II. The chlorite group. Clay Minerals, 25, 83-92.

Yamato P., Agard P., Burov E., Le Pourhiet L., Jolivet L. \& Tiberi C. (2007) Burial and exhumation in a subduction wedge: mutual constraints from thermomechanical modeling and natural P-T-t data (Schistes Lustrés, western Alps). Journal of Geophysical Research, 112, B07410.

Zang W. \& Fyfe W. (1995) Chloritization of the hydrothermally altered bedrock at the Igarape Bahia gold deposit, Carajas, Brazil. Mineralium Deposita, 30, 30-38. 